\title{
STEAM PLOWING.
}

DESCRIP'TION OF THE OPERITIONS

OF THJ:

$$
\text { WIJLIA MS S N }
$$

fload feamer and team flow, (1) THI:

Seed Farmi of Messirs, David Landireth \& Soll,

11

BloOmsdale, NEAR BRistol, PA.,

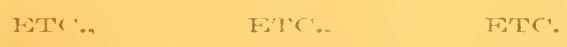

D. D. WIIIIAMISON, No. 32 Broadlvay.

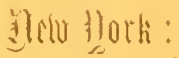

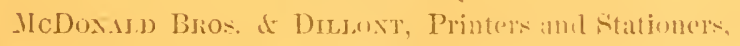

No. is l'ark Pliure.

$15: 3 \%$ 


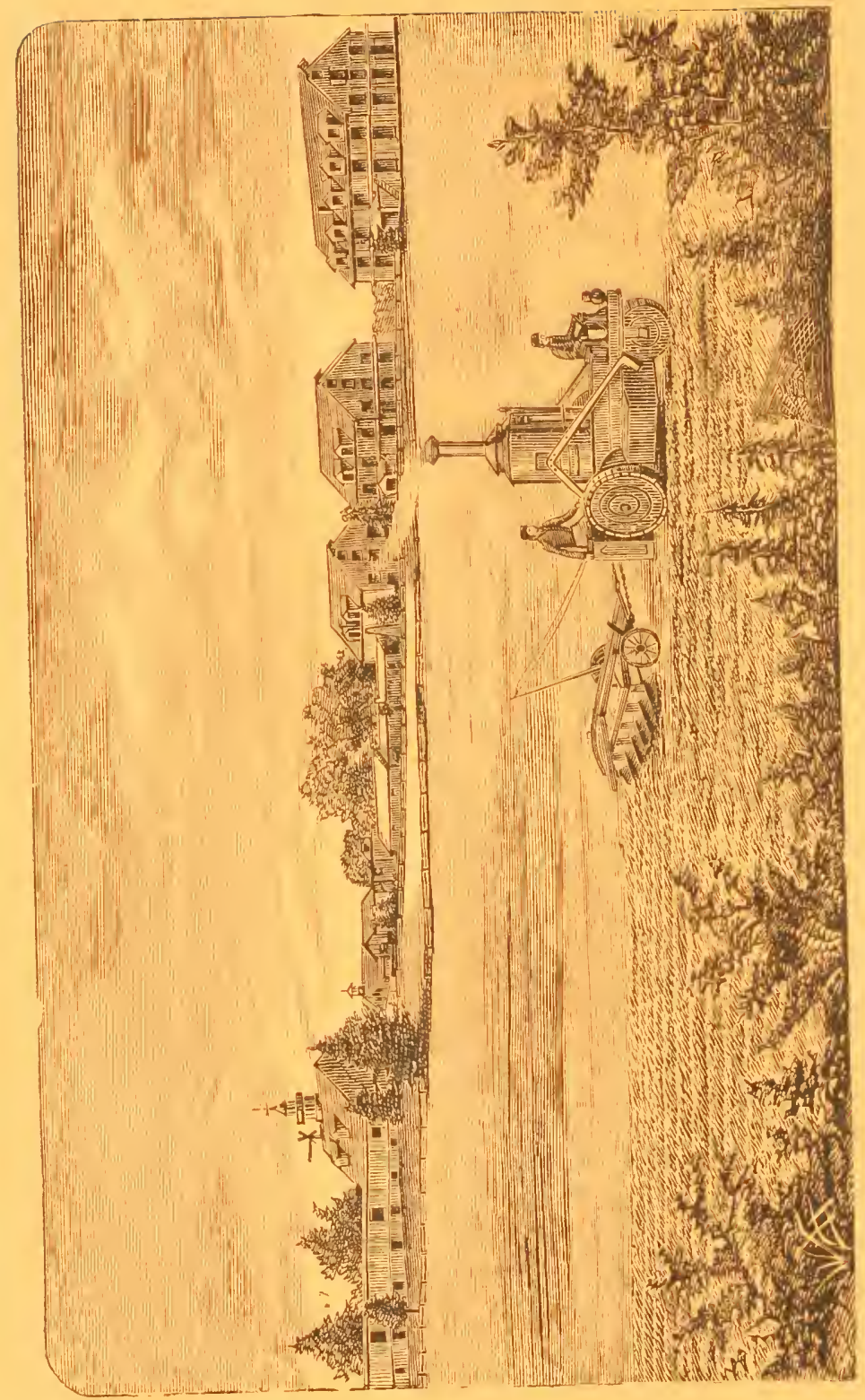




\section{STEAM PLOWING.}

DESCRIPTION OF THE OPERATIONS

()F TII

$$
-W_{11} \text { ILLIA MSUN }
$$

fload teamer and team flow, ()N TIIE:

Seed Farm of Messss. David Landreth \& Soll,

\section{A'}

BLOOMSDALE, NEAR $\beta$ RISTOL, PÁ.,

$$
\text { Hive, HTC., HTC. }
$$

This Heamer and llow bas received the firs prize, continting of fold Medals or Diplomas. at every Fair at which it lus been exhibited.

D. D. WILIIAMSON, No. 3: Broadway,

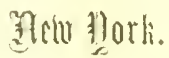





\section{No. y2 BROADWAY, \\ NeW York, D) E'EMHER, 18\%:.}

Fine principal object of this Pampinlet is to present to those who are interested in the subject of Steam Conltivation, the opinions of a mimber of gentlemen well known as advanced agriculturists, who, having no interest whatever in the system amployed, have printed simply what they siw, and the con"hisions they formed after witnessing the operation of a Wil. lianson stram Plow at Bloomsdale. In the following pages will be found $\mathrm{AL}$ L that has been printed on these trials. whethe farorable or otherwise. The opinion of a gentlentan so widely and favombly known as David Landreth, Escy., formed after actually riding npon the Stram Plow day after day as it crossed his beantiful firds, and watelhing the thoroughness and celerity with which it worked, is alone of inmonse valne ts, those who have been anxiousiy wating for a stam Plow alapted to American fields.

Another objoct in rollecting and yoklishing these articles, is to distinetly ronnect the name of Landreth with the earliest practical working of Direet Tratetion Stean Plows in this conm try, as well as to perpetuate the rementuraneref a most enjoy able day, when a gathering of notable men (amne to examine rritically the stran Plow, and to enjoy the bomntiful hospital ity of Bloomsdale.

That the English system of Rope Traction is considered as not adapterl to this conntry is amply proved by the fact that the import duty on these Plows has been renoved, and for the past two yeall's they conld be landed here at an aldrance of "nly about 8250 to $\$ 300$ on their cost in England, and yet none have been improrted. Their best results have been published, and are well understood by our intelligent Fan'iner's, but the "onviction has ever been strong that the American stean Plow must consist of a light, powerful steamer, drawing a gang of asily managed lplows behind it. Thanks to Mr. "Thomson, of Scotland, his rubber-tired Road Steamer has given the cue from which, after successive improrements and radical alterations, 
the Williamson Road Steamer has been perfected, and thimotor, with the Williamson Gang Plow behind it, has now proved itself capable of plowing; with reasonable eronomy, all land in fair condition, which is arlapted to Stem Cultivation.

The failures in plowing by direet traction in England hatre simply proved that their heary rigid-tined Traction Engines and ammersome Plows were entinely unsuited to the work. As well might an attempt be made to mavigate our shallow rivers with their maguificent orean steamers.

Nor are the Williamson Engines to be confounded with tha. Romd teamers built by the Lieremsers of Mr. Thomson, in Grealt Britain (ol" whireh about 150 have been constructed), as they alre laddically different in many points which are vital in sitram Plowing, and which alle the result of much actual experience int the firdd.

In addition to the aleomnts of the Blomensdale trials, there areathed a few extrate from different mewspapers, showing what the IVilliamson steamers and l'lows have been doing in othere parts of the comitry.

Beresering that the Steam Plow is to play an important part in the derelenment of one cenntry, the publishing of this Pamphlet may prove a not mimportant contribution to its history.

I). D). WHATAMSON.

PL()IIING HY NTFAM.

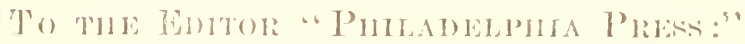

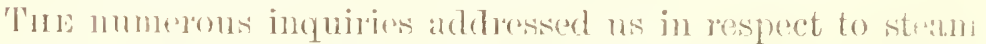
plowing by dired tradion, as opposed to the more anmbrous and costly "double engine and rope system," induees us to requent apase for a fow remarks, whish may interest partios who desine information as to omr experiments at Bleomscille.

Thar (ngine used ly us mainly, is the three-whoced. rubber-tired, of Thomson, of seotland, improved greatly by Williamson, of New York. the American patentec, and sole builder in this eomity : one with four wheels, the drivors being fitted with rubber tire, (also by the same? fruty) has been axperimostad with, but the first named excited most 
Intemest. and probably will be generally preferred; though the latter has some good points which are not to be overlookerl.

In this communication, we shall contine onrselves, however, to the three-wheded engine, the special adrantages of which arefully ret forth in various publieations on the subject. to which the reaker is refered.

Oul experiments were commenced in Allonst, of the present year, ander the direction of an airl of Mr. Williamson, who thongh not a professional enginere, was quite an expers in mechanies; he proved to be ever realy to acknowledger minor aefoets as they were axhibited from time to time, and prompt in ar desire to amend them.

At first some difinculty was found in stering the engine, so as to have each furow-swath regularly and uniformly lap the preseding, but a little purctice orercame the inclination to vary from the proper line. The Williansom Plow is a gang of five or six plows (five loring principally nied), of steel, and are affixed to an oblique rigid beam, so inclined as to carset (a) foh furow slice to fall into its proper place, and with levers so adjusted as to rum the plows to the desired depth, say eight inches, as in our trials, though a shallower or deeper depth maty lne adopted at pleasure. Eatch plow turns a slice of fourteen incises, and when five only alre nsed, the breadin simultaneously tmoned is nearly six fert. The speed usmally excereds that of mules or horses when engaged in plowing. and wh have, without difficulty, accomplished an acre an howr. STith areater experience and proper facilities for supplying fuel and water, there is little room to donbt eight ateres a day, with full allowance for detentions and stoploges, may be sot down as an arerage result. Indeed, we hope, with increased furatice, and the more thorough removal of obstructions, to excesed that aread.

It is not, howerer, flom the plows that we look for the most imprortant results. but from an implement, termed by tinte English a "lopaker," which is simply a series of iron condters or sub-soller's, so armaged on a frame as to cover a breadth of nine feet, which, as it offere less resistanee than plows, moves with greater facility, and prepars many acres a day. This breaker is designed at one operation, to disintegrate and pulverize the surfice soil, and also disturb the laard pan below-it may be montls alter it has been plowed-and with a luarow attachment used simultaneonsly. 
lesve the surfice smooth and ready for seeding. Practival men ran at once perceive the advantage of this process.

In our own culture, with five hundred or more acres to prepare for seeding, if possible betwixt the opening of spring and first of May ensuing. it may be difficult to estimate its value. enperially as we propose to execute the plowing in autumn, and early winter-only using the breaker and harrow in spring to lighten up and further disintegrate the soil. Such, it is certain, may be a frofitable practice in the preparation of ogt and orom lands. and also emphatically so with the exhanstter cotton lands of the south, allowing the plant as it weres, to revel in fresh pastures; and with an imperfect knowledge of rice conture, ohtalined by castal observation, we de mot hesitate

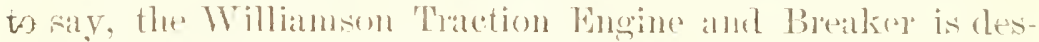
tined to resover our ahmost abandoned interest in that arop. Not only will roppling be thus farilitated, but it the experi-

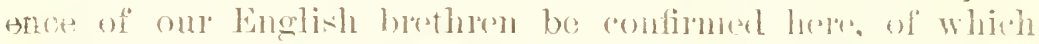
there an bes no dould, anlarged produrts will atternel the more thorongh tillage which stram power may enalule us te pratetice.

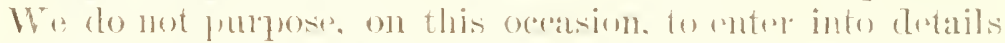
as to the relative rost of muscular, animal. and stram plou-

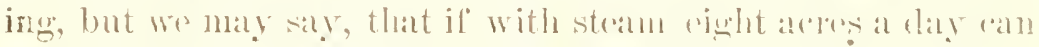
be comented on as an alverage day's plow inge and twiere that nember with the brakes, theres nexd bo no question an to its wonemy on large plantations; nobody, it is presumed, inag-

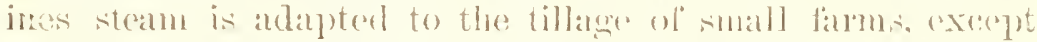

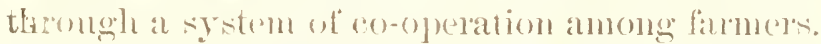

It is hardly necessing to saly that, in addition to plowing, the Williamson steamer will be of eleat servies in hatnling farm prodnce and manure, threshing gratin, sawing wook, grinding fertilizers, and in many similar employments, whichs the progressive farmer must adopt in self defence.

DAVID LANDIRTH \& son.

Bloomsdale, near Philuthplia, December, 1872.

Havise been fortunate onough to receive an invitation from the Messrs. Landreth to be one of a comptiny of agrien]turists alled together at Bloomsdale, on the Sth of November, to witness the working of the Williamson Roal and Field Engine, I am induced to make certain notes of that 
pemarkahle exhibition of a new applieation of steam, and the reflections incited thereby.

The enginc in question, is one made on a plan originally dexigned by Mr. Thomson, a Scottish eivil enginerr, but huilt and impmoted hy D. D. Williamson, Find., of 3:2 Broadway, Now Yonk, thr Ameriean patentee and sole manufacturer in the United States. The complete engine weighs between six and seren tons when ready for work, and is cajable of exert ing a forme of eighteen or twenty horse power. It is supported mom two large driving wheels, and npon a third and smaller wherel in front, used for steering. "The total longth of the engine, is thirteren feet, and width nudse seven feet. The boiler is made of strel, and is an upright tubnlar, thirty-four incher in diameter, fixed between the driving wherols, which are five feret in diameter, and fourteen inches hroad. In front of the boiler are two cylinders, six by ten inches. other machinery and steering gear, all in elarge, and inmediately under the eye of the engineer. Back of the boiler are the coal boxes. furnare and platform for fireman, who is charged with the eare of the plow or wagen train. The construction of the rarious parts of the engine is althongh very perfect, not particnlaris remarkable. the noveity of the machins lowing in the number and arrangement of its wheels, and in their enstruction, wheh pnahles it to be tmmed in less space than that required for a carriage, and distributes its weight upon the gromen orea a broad surface.

'The wheels of all suecessful self-puropelling engines wete, before the introduction of the Thomson wheel, and rexepting the one in question), are yet made with rigid iron tire, which neressitates the appliation of diggers upon the periphery, to give then snfficiont griv on the ground to prevent slippingthese "diggers," althongh not so objectionahle on the farm, are Recidedly so on bard roats, as the works are injured by the contimnal jall, the mathine walking, as it were, on stilts; and the road if pood, is serimsty at "llp. (The IVilliamson whert has alse prevision for "diogers." hut they are seldom requirea.)

But the alyplication by Mr. Thomsen of a rubber tire fozar and a half inches thick, and twelve inches broad, not only ovoreomes this difficulby through its elastieity, hut, by the weight of the engine. the rubber is thattemest out as the wheels revolve, thus increasing the bearing surfite non the ground from less than one lnudred square inchescas it wond be with au inflexible tire), to six hundred square ineles with the l'ubber. 
It is in this increase of bearing-surface where the rubbren. tired engine has its advantage over all others, and the adrantage is two-fold-first, giving the machine such at tenacions grip upon the ground that it is propelled forward under circumstances when the wheels of an engine of smooth, rigid tires, would revolve withont effect: and serondly, in distributing the weight to such an extent that the pressure per square inch is not greater than that of a horsis foot, als can readily be perecired by examining solt land ores which it has passed.

These rubber tires alle of vulcanized material, expertsisly prepared for this purjoste and have been thoroughly tested int sootland, where rumbers of engines are in nse, the tires of

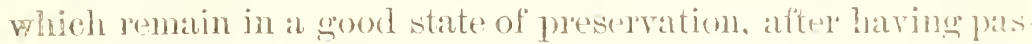
sed over many thomsinds of miles.

The better way howevor, to describe its wonderful ral are iby, is to state what we saw it do at Bloomstale. the moter

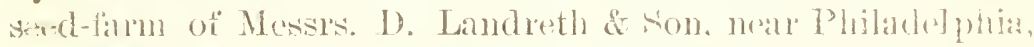

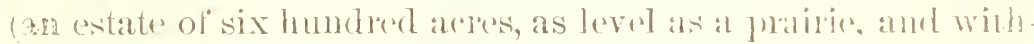
ont an obstructing femes, diteh or tree ; this andmimaly andapt ing it to the use of just such a machine ats wo there saw in operation.)

The rompany the are assembled, although they hat all sinen other tration and plowing engines at home an d abroal. Write

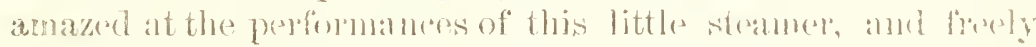

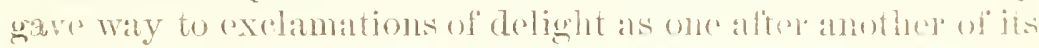
powers were exhibited.

It first ran at a rate of eight or nine miles an homr, 11] and down a long wasgon road, and then into al rourt-yad where it

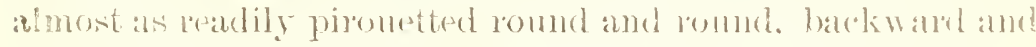

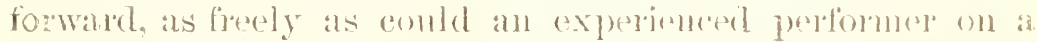
velocipede. Then up and down, forwand and hatekwald start-

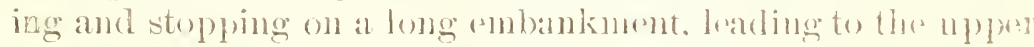
fioors of an elevated stone barn, and on which the grate was abont one in five.

Then it was attarehed to two farme wagons, which. whern falled with abont thinty persoms, it dew at a late of rix miles an homs, a distance of two miles, aromel a portion of the

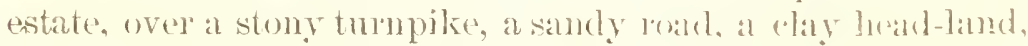

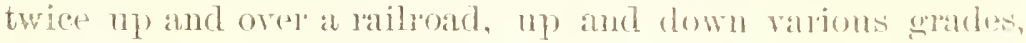
and throngh mud and mire, the rain haring fallen ins torrents the daly before. rendering these tests all the mer. diflicult. 
Next it connected with a gang of plows, and drawing them to the fird, entered upon its severest trial, but without hesi rition.

The order was given to go forward, when away it went, fuming with five laroe, steel plows, rumning seven inches drep), a swarth of six feet in bleadth, of very stiff blue-grass sod, the growth of many years. Puff, juff, putr, went the 'ngine, and if the company had followed it around the field as lapidly as it movere, they would have puffed as well, for it delayed not, but turning out as it successirely arrived at the 'nds of the field, re-entered withont stopning, and in less time than a minute, and so on continuously, until the company wero fully assured of its almost fabulous power and a a jacity. We were told by Mr. Landreth, that it had repeatedly and conseentively turned with the plows, ont and in at headlands, in thirty seconds, the widtl of headlinds being twenty-foum feret.

The practice at Bloonsuale, when preparing a fiold for stran plowing, is to mark out a headland eight yalrds in width at each rond, and a strip of the same width on each sicke, and when the field is finished to plow around the belt, thus breaking up the entire area withront difficulty.

Upon this occasion the plows mexersed fire hundred cubie inches of soil for every inch of forwarl noventent, butwe wele fold that the engine had daw the plows y uite readily when romning twelve inclies derp, then leversing eiglet th undred and sixty cobic inches for every inch of forwat morement, al 1hongh the difficulties of plowing incose in a greater ratio with an increase of depth than with an increase of width, which fart is not generally considered when miking comparisons in plowing.

From my observations of the day, which were thorough and decisive, I ronchucte that the Willianson Stranter, as a loadstre, is so rapid in its movements, so powerful in direct tratetion, so woll adapted to driving mahinery by means of belting, and in all situations so easily handled and so mnlike$1 y$, fitted as it is with an improved spork-arrester, fo firo build ings, rven when placed immodiately alongside of then, that it may be safoly said there is searely a limit to its nse.

On the farm to plow, to haul manure, to thrash, to saw wood, to grind com, cut folder and la! and atean the mix ture for stock-feeting, and perlaps, before long, to proped a mower and reapel over fifty acres at day. 
In the stome quary to lift and move ponderems blocks.

In the ship-yard to transport and raise miglity timbers.

On the catnal to haul hoats.

In the ronstruction of railroads, to hand wath from the "ut tings to the emuluakments, and distribnte the tiss and rails.

In transporting frasengers and freight, in districts where there are no railroats, or as tributary to existing railroads. With suitable carriages attacherl, a steamere coubl l'm any ditance, provided the surfares wre snital)le, with thirty or forty passengers, and at a rate of seren miles an hour-thus dered. oping and preparing a distriet for a line of rails.

On the wharres and docks, in loading and muleading vessels.

In raing the stones, incon, and lumber, used in the construrtion of bubldings and in a multitude of similar molnoyments.

In most of om rities there would be employment for seores of angines and these would forkably be owned by ampanim

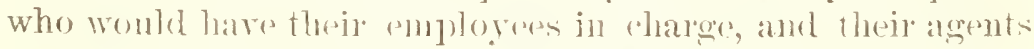
looking after fresh work. so that no somer would one job ha. finished, than the enginn. with the rigering nesessary for its work, romtel move ofle ats rapjelly als an ordinary wagon. to another find of labor, already designated. It may be asked. cannot any tration engine do all these varions works on the.

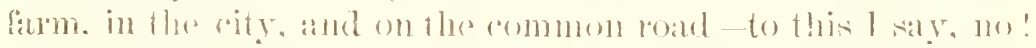
The Wiblanumem Engine alone besing able to fill all the re. (quirements, beamse of its peroliarly comstructed wheres. giv ing it such wonderful powrer and tareility of morement.

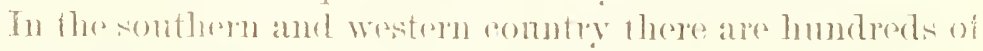

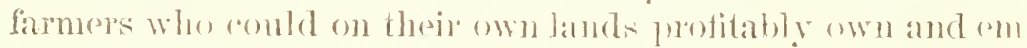
ploy a Wrilliamson Steamer. Jut for those of fewer alceses, and for the majority of farmere in the East, a system of ex(1-0) rration in the purchase and manatement would be best.

They could lave their lanels plowed, lumber ent, glain thrashed, and corm shelled at such prices, and under suel rules regulating the question of presedenere, ats they might adopt. The profits of the rear to go into their own jockets-they themselores being stockinolders.

The produrtion of stram-tilled lams, it is probable, will greatly increase, as the land will be cheaply, promptly, and deeply plowed, thus fareilitating the oprotion of seeding, and encouraging a morevigorons growth of plant. The farmer, not. only emithed by an inereaserl froduet pex acere, but hoth he and the exmmmity benefited by the saving of those levgr 
quantities of grain and hay mono an mually consumed by the horscs engaged in the nery work to which the engine will be appliad, it froding on the production of the forest and mine.

The Poyal Agricultural Society of England appointed last year a commission to decide upon the best managed steromtilled farm, and one hundred and forty were deemed worthy of inspection. L'pon these the reduction of horst-power under the new erat varied from ten to twenty-five per cent., and was, in two cases, as much as sixty. Thin is all the more remarkable, whem it is considered that the farm produce to he handled is an arerage of thirty-three pere cent. orer throld systrm.

When at Bloomsdale, the statement was made that the proprietors estimated the ammual cost of horse food at marketprice (the food there bring all purchased, not any produced), interest and depreciation on their stock at two hundred dollars: pere hear.

In the South and West the value of stock, and cust of keeping, is lesis than half of that in the East, but supposing that one-half of the stock of horses and mules in eight of the Westeru States aro pugaged in the enltivation of the land. and on this making a lechuction of eighteen per ent., which is proved to have then the arerage reduction in England, and estimating on this an anmul siving of expense of fifty dollars a head for foed, interest, and depreciation, we have a saving of thirty-five millions of dollars ammually.

These jfrms induce the thought that it would be interesting to work ont a more accurate and reliable estimate of the gain that womld areche to the agricultural community, growing out of reduced stock in tillage, and the increased prodnct, the result of stean "ultivation, throngh even a partial adoption of" this new system.

Before the sncessful adoption of steam plowing, however, our farms must be thrown into larger tields, and eleared of all unnecessary fonces, headlands, trees, stmmps and stones; and this very respisite alearing ${ }^{11}$ ) and re-modelling will bo of benefit, increasing the area of tillage-land, and more readily allowing (depp enlture, and, as a comsequence, better dramage. And when it is comsidered that every additional inch of soil brokeu up and made productive below the ordinary kepth of culture, gives one hundred tons in which plants can more fully derelop and draw nourishment, it must bo erident that deep hrealking of the subsoil, will, under all circumstances, bes 
beneficial, esperially on lands worn ont on the surface, as are most of the acres of the older Southern States.

Fenees are a great impediment to steam cultivation, and if it should server to direct the attention of agrienltmists to their almost entire muprofitableness (except to fence in stork, not fence ont road cattle, as at present). and waste of land which they occasion, it will be doing another great work. It has been estimated that the first cost of all the fences in the state of New York was one hondred and fifty millions of dollats, and that the ammal tax for fencing on each acre of improved land in the Union, is one and a half dollars. (solon Robinson.)

As to the question of the economy of the Williamson Engine, as compared with horses or mules, a reatomally acerrrate conchusion can be reached by the following calculation: assming that a patir of mules depreciate two-thirds in value in ten rearis, and that their original cost was four humbed dollars that, at six pere cent. simple interest for that time,

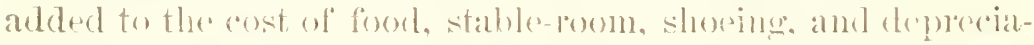

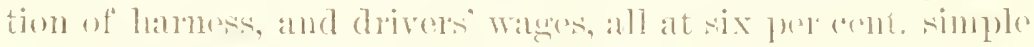
interest, we latrea daily expensere of two dollats and righty-

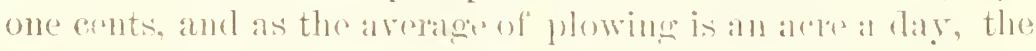

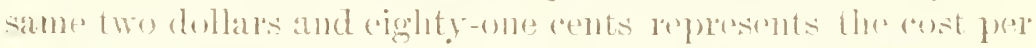
acres.

Now, taling the Williamson Stramer and its gang of plows, at a cost of firr thonsinel dollats. and as amming the same depereciation of two-thireds on its original rost in terl

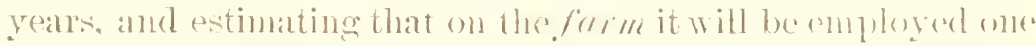
humbrol and fifty days in the year (in many other sitnations the employment wonkd be mene constant. and thenefore less

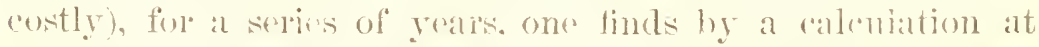

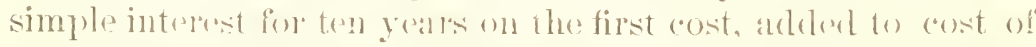
ome hundred and and fifty dalys work each year for terl years. for engineer at three dollars. firemall at two, cost of wal and cartage of water at five dollans, and wear and trall at ten pere cent. per ammm, all at six per eent. per ammm for the terl years. and estimating the value of the angine them on hamel to be one-third of the original cost, one has for the fifteen lomdeed working days within the ten years a daily eost of cighteren dollan's and thirty-six arentis. Now, supposing the engine plows right acres a day, we have a cost of two dollaws and thirty cents per acre, as empared with two dullars and eighty-one rents by horse powel, to say nothing of the supe- 
rineity of the work. On looking at it in another way, the daily cost of the engine only being that of six and a hall pair of mules working in the tield, while it dows the work of eight pair:

1 mere stimate in clellars and aents of the companative cost pere ace of plowing by hoxse and by stesm pow re dor's not, howerer, show the advantuges of the latter to its fullest axtent. Eren if the cost of plowing by stam was greater than ly horse, it would, in the estimation of large operators, have the preference, as by the greater capacity of steam they would be ellabled to push forward work, net stopluing for luat on' dronght, and prepare land for seeding in due soison, whilst others, dependent on animals, would lag behind.

On all oceasions when the steamer wonht be enployed as a stationary engine, the engineer would art at fireman, and frequently bum wood, the production of the fasm, instend of eual, thus reducing the expense quite fivo dollars a day.

A set of Fowler's engines, with tackle, 'ammot le hat for less than ten thomsand dollars, and requires two enginesers and four or five men to manage the ropes and inmlements, necessitating such an expense that it wn only he profitable where the work is constant, and the fields repy large, for, with the rope systrm, it takes an arerage of two hom's to plit down and tak up on a fiede all the impediments of the Engrish system, while, with the Wiliamson birect Traction Plowing Engine, the time taken to move from lielet to field is only that which woukd be rexpired to mexe at wasem, and when it arrives at a new field, is immediately reaty to go to work. All the valculations that the writs has erer seen of the daily cost, or eost of plowing pere ale by the rope system, have been very defective, the interest, and war and tear, either minely mitterl, or the greatly defiejent in amount, while ome will slways find chatgerl the small items of oil and cotten waste.

The use of the stram plow will fimiliarize ítrmer's with mathinery wheh will have a benefitting influesee, inducing in them at greater desire for injmorement, ank habits of themghtfulness beyond the ordinary routine of the the falles's, who, thongh they may hare besen good farmers in their gemention. would cont a sorry figure in this age of reapers aml mowers. and of stean and chemistry, ats applied to agrienalture.

Agrienltare is inderel taking great strides: no firmer should work in the dark, though. alas! too many do ; the besis excuse 
with the many botanists and vegetable physiologists, to tell us of the lakbits and structural derelopment of plants, with the many chemists devoted to their science, as applied to agricnttu1e", tearling the ohemical organization of veretablesubstances, and of the kinds of manme plotitalhle to a phly, and with manufarturers of fertilizers oflering us atticles of swom eommosi-

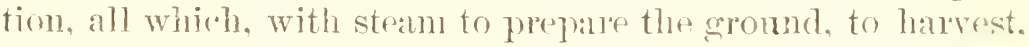
and thrasle the crops, dull must he low who fails to malie pro(20)?

Indred, it seems that modorn agritulture may become a soionce, not simply an art, for the porsonal attention to details, kesen observation of the habits and fomation of plants, and rhemical and mechanieal knowlecloe nexeded to eally on a sure. cessful system of larming will. ro lomg, lauk in intricary with the deegest of those studies rallod the "sciences."

November 15, 18\%?.

$$
\text { A BICKS CoUNTI HARMzR. }
$$

[COMMUNICATED TO THE: "HARYAND FaRMER."]

\section{REPORT OF TRIAL}

(1) $1 \%$

\section{WILLIAMSON'S ROAD AND FIELD STEAMRR.}

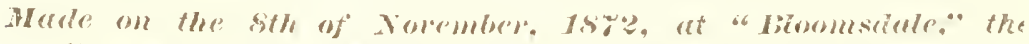

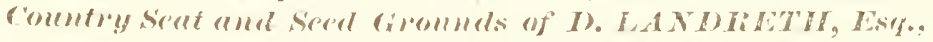
of I). Lambleth of Sem, I'hiluetghia, l'a.

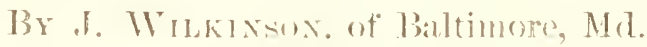

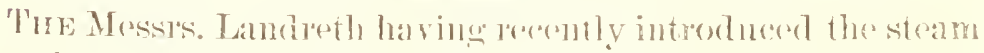
plow in the fillage of theiv six humblind are soot grounds.

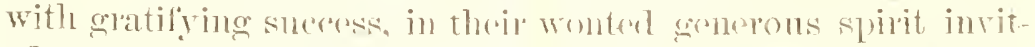
od a $110 m$ ber of friends to risit then and witness the working of this molern motor for plowing. hanlings este, on the farm, among which friends the writer forels that he was fortumate in being inchuded, as the oceasion was most interesting. Thonesh

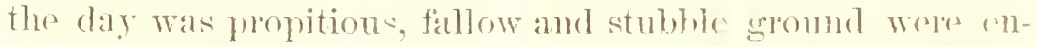

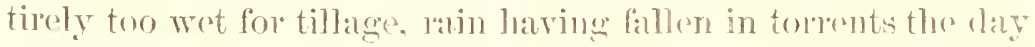
previons, but on host seemed dotemined we should not bo risappointed in seeing the steant plow perform, so ho ordered it into a favorite, long-standing gasturo, which was a linom 
swarl, apparently fert cxalusively as the home of a trio of lesatiful Alderneys, part of the adnimable Bloomsdale lerd.

SILE (IH THE: LOT.

The lot in which we were obliged to plow was rather short, it meastiong only two hundred and filty yards in the direction of the axis of the furrows, as in plowing by direct traction. musth is gained by lomp "lands," - th: minimum shondel mot be les than three hundred yands, hut this field was favolable

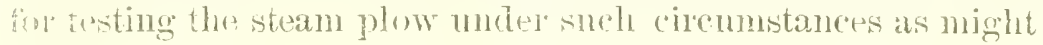
txelli:

'l'he engine turned ont on the headiand at rach end of thr. bot. and sot in again without stopling, only losing each tuxn, perlages thilety secomds of time.

THO ENTIXES FXIIHITED.

'l'wo soli-jorpelling stramers were exhibited to the com-

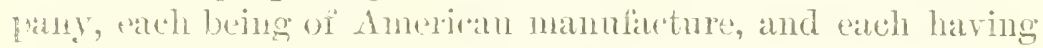
rubber tires on the driving wheels.

One a form-wheeled engine with ' compensating gear," having" hnt one cylinder, and a lonizontal boiles, the power being nominally trin horse, but actually nuch greater. The general appearance of this stermer is similar to the Huglish engines. It was made especially for farm wotk, such as plowing, thrash ing, and loanling, and althongh purreftul, and doubtlens a very eflicient engine, it appeared to be cumbrous and slethoris: when compared with the second angine, to which onr attention was especially directed. This latter is supported on thres whoels, two, the drivers, sustaining nealy the entine weight of the engine-the thind and smaller wheel being affixed in front, and used for steering, as is the fromt wheel of a velociperle.

The driving wheds arr filty-eight inches in height, and sixtren inchus "lace," the steering wheel thirty-four inches in height, and thirteen inches fitcr.

TIIE DRIVIXG WIIELS.

'The peculiar construetion of the driving wheols gives them great superiority over all other whes for traction engines. for which the world is indehted to Mr. 'Hhomson, C. E. of seotland, and to Mr IVilliamson, the mannfateture in this comntry, of these road and field engines, for valuable ini) rorements. 
The Thomson wheel resembles a inge hollow pulley of iron, yet light and strong, the dimpnsions the same as those above describod; its periphery being perforated with half inch holes. Surponding this perlorated iron tire is a continums band or tire, of vulcanized rubber, fom inches in thickness, and sixteen inches in width. Outside of this is an endloss ehain. formed of stesl plates, ach plate heing fonr inches in width. and of a bength to extend arders the fivee of the rubber tire.

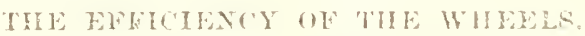

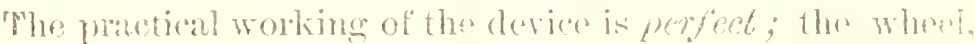
as it revolves, thatens ont at its bearling, by the weight al the

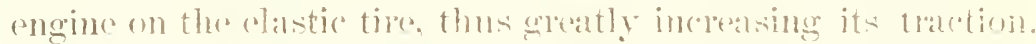

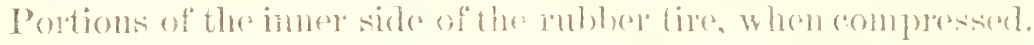
protemere into the perferated face of the iron whol, to whish it

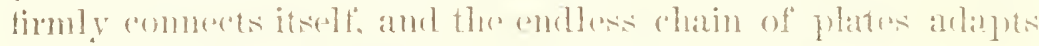

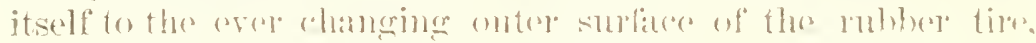

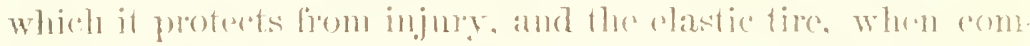

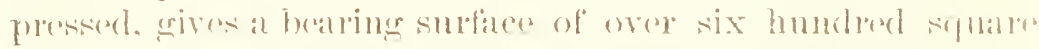

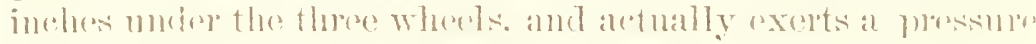

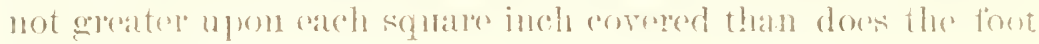
of a horses.

The efficitency of this traction wheet, a truly wometernful juvention, is attributable to the listribution of the wrobht. and inerased impart upon the surfare on which it revolves.

The American mamulaturer has mate a decided impurement num the seoted wheel, above describod.

It romsists in substituting short secgmental lagss. or howks of mbluer, for the expensive eontimmons tire, or hand of this material, and hy fitting the wheel to recerve "digegers," so sis to prevent miring in swampla lancl, at the sime time retatining the principle of compressibility, so invaluable in at tration wherel.

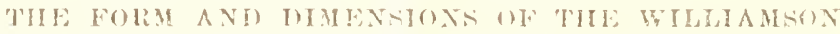
ENIIINE.

Mountere upon there whorls is an npright steel boiler. the height of which, with the smokr stack, is but ten fore from the gromil.

ln front ars two horizontal rylinders, each six hy ten inches. with the works, water-tanks, seat and stecring aplowatus for the engineer, who is pilot as well.

Back of the builer are coal bunkers, and platform for fire 
man. who also acts as superintencent of the plows. 'The lank holds watro for two hours' supply, and the bunkry coal for fonl hon's, and, with the operatow on board, the rngine weighs a little ores six tons.

COAL CONSUMPTION.

'Tho ("oal consuned per diem averages about three guaters of a ton (hitmuninous), and of water abont five toms; this anount will, howevor, be greatly reduced by an improvement

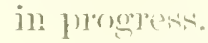

'The nominal power of the engine is eight horse, but it is capable of exerting nearly three times that power.

\section{LNSTONS.}

The longth of the engine is thirten feet, the width six and three quartix feet.

TIIE YLOWT.

The plowing apparatus consists of a frame, with a gring of five to eight plows attached; each so arranged or set as to cast its furrow into that of the plow proeeding it.

Whe width of the belt plowed of the sward, which 1 wit. nessed, was alont six foet, and seven to right inches in repth, thongh the powere of the engine was evidently gajable of plowing a mowl geater width and dopth, as it has plowed at Bloomsdale. seren feet in width, and ten inches in depth.

SHIDI.

The spoed with which the plow advanced was about double that usually male ky mules or horsos in plowing.

'The soil was neally foee from stones and rocks, and was thoronghly plowed. All present promomuced the steamerand steam plowing empluatically a sucress.

TEST AS A ROAI TEGINE.

Prion to the exhibition of thr engine in plowing, the engi neer plied if sevaral times 110 and down a famm lane, and ran it up anome buillings, whore tho tums must necesarily be slont, and be made with plesicion: ho also exhibiter valons reloripedian performancess with admilable skill, and satistied all that the ponderous iron lonse could tam moll quicker; and on a less area than would be regnimed to tum a pair of horses attacled to a farm wagen; or, to be more explicit, it can 
be turned completely around in a circle of eighteen feet diameter, as either of the driving wheels can be made to serve as a pivot.

This engine can be run readily on a common road up to ten miles an hour. The elastic tire serves as spring's, and relieves the engine from the injurions effects of concussion.

One of the most remarkable performances of the steamer was to rum up and down, forward and backward, stopping and starting at pleasure, on a hill hiving a gradient of one in Aive.

1'ERFORMANCE ON A ROAH IN IHAULNG A TRAIN GF WAGONS.

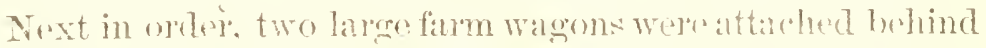
the stramer, wath fitted up with loose seat hatids aldoss the body, and as many as conlel ride wore seatrel, when she

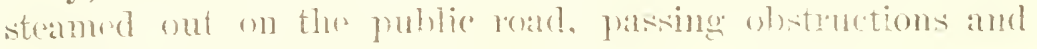
aroiding gate posts in admirablesty.

When onere in line on the reale not mulike the spirited trotter when he strikes the tratek. onr inom hopese semed sud-

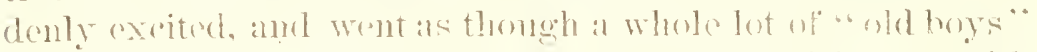
were alter him. Fortumately, the road was a fili? ones, with here and there a stone. Sufferent to give us at good shatking.

We spex away a cirenit of some two on thme miles. and returned to the starting yoint, by entering the domatin on the oppesite side frem that at which we left it. and arosered by farm roats. through an area of fifty arews or mole. which hat resently beren plowed by the engine. The work appeared to

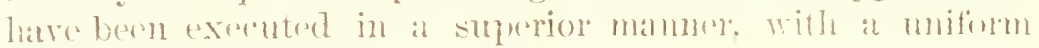
depthe of nine inches.

Wo next witnesod with intense interest tlu plowing of the sward, of which I have spoken, which was antimed motil the novelty was slightly waning, when wo wer informed that

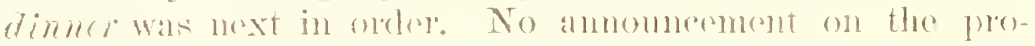

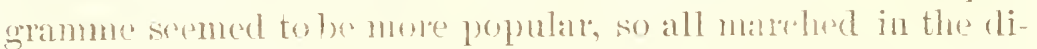
reetion of the large national flas, which wared overe the mansion, hidden for the moment from one view hy the stately, venerable trees that surromed it.

During the errening many sulyjects of general interest

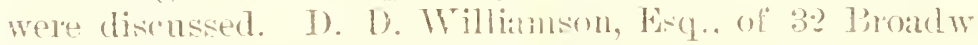
New York, who is the sole mambliatmer in the Lnited States of load and field stramers, with Williamsen and Thomsonts fatent whesels, instructively related the history and the many advantages of the steamer. 
The disurssion of the construction of wagon poadsocenpied a considerable length of time, though not a moment more than, on accenut of its importance, it deserved.

The exrmplifieation of the efficiency of the Williamson Enrine as a roadster, for hauling both passengers and freight over common roads. especially now when we ale laboring under such inconveniences oceasioned by the rpidrmic among horses and mules, made the discussion of its merits a mattej. of intense interest.

The fombling of towns and cities, the construction of dwellings, sourees of water supply. landseape gardening, for estry, pisciculture, Pertilizers, etc., each shared on considera tion. There seemed to be a general concurrence of opinion on all topies discrussed, and nothing ocemred during the day to mar on social pleasures.

Had I space, a description somewhat in detail of Bloomsdale. the system of cropping, the implements and machinery nsed in cultivating, havesting, and preparing for market the great variety of vegutableand flower seeds there grown, would he of interest. Suflice it to say that fifty-eight head of horses, mules, and oxen, are nsed on the farm, and its dependencies, and four stean engines, beside the Williamson Poad and Field Thaction Engine about to be permanently added; twenty-five thomsand dollars worth of fertilizers are annually applied, in addition to the mamure made on the farm, and eroy variety of implement and machine nsed in agricnlture and horticulture in this ronutry, may there be found, and what we saw there were sufficient to stock a rospectable wamohoms.

Everything is in orler, and system, neatuess. rood taste and fitness of things, pervade the entire establishment.

The seerls grown at Bloomsdale, and on other lands owned, acenpied, and operated by Messrs. Landreth, are exported to the shores of the Pacific, to Australia, and the British Possessions in Inclia; in tine, their seeds are said to he almost as well known on the shores of the Ganges, as on the Missiasippi, or Ohio.

[From "The Practical Famier," Philaderpha, Decenbez, 1872.]

\section{INAUGURATION OF A NEW ERA IN AGRICULTURE. \\ Steam Ponere on the Farm and Common Iionds.}

$\mathrm{O}_{\mathrm{N}}$ the Sth of last month, in ('omplany with a number of other invited guests, we were present at Bloomsdale, near 
Bristol. Ponnsylranial, the residence and well-known seed farm of David Landreth, containing over tive hundred acres, to witness the trial of a newly invented steam power, all ad the Williamson Road and Field Steamor. The insentor, 1). D. Williamsen, was present, and the steamer, which bears his nanle. is an Amerioan improvement tipon the well-known Thomson Road Steamer, as constructed in Croat Britan, and is now believer to he. with these improvements, perfoctly adaleded to road and fim service in this comntry. The Amerian inverntion. which has overeome all previons diflenltirs, consists

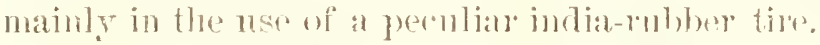

IT. had an illustration in the Prorefiral Farmer, of 1871.

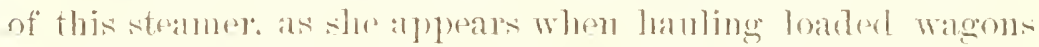

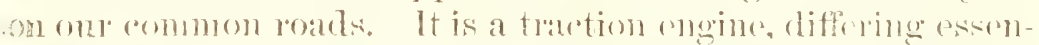
fially from English stram plows, where two stationally ruginos

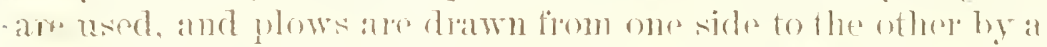

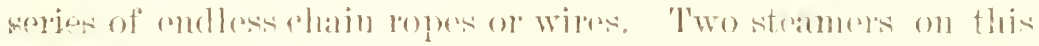

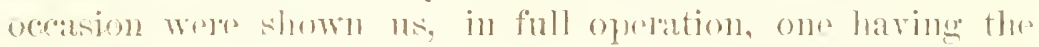
"ontinuons rubber tim, and the other having the time in sere tional bleckes.

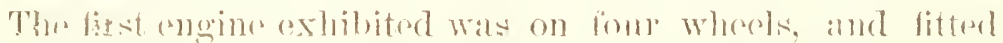

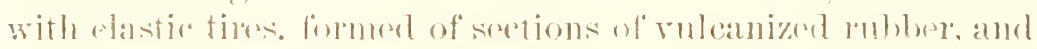

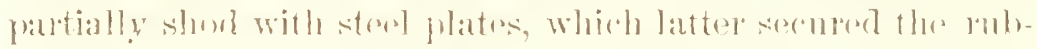

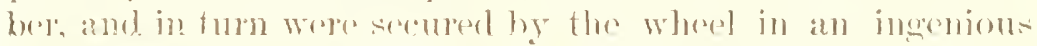

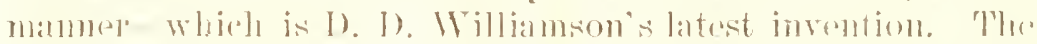

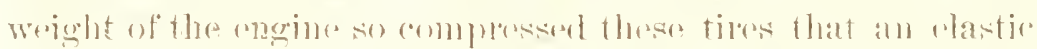

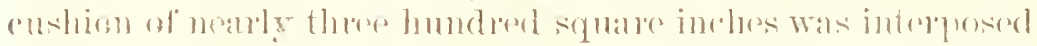

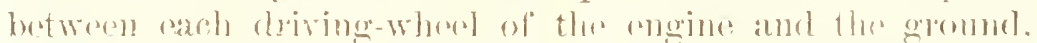

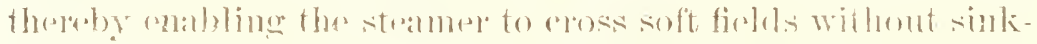

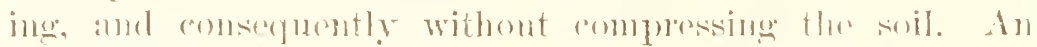
ingenions rontuensating gear anabled the stratner to turn in roly small space, withont slippling tho whools.

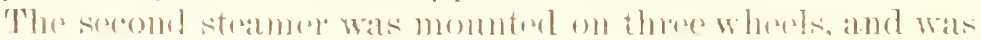

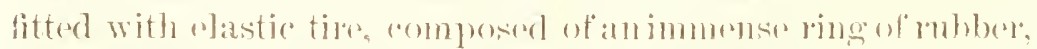

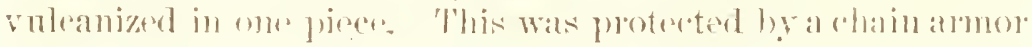

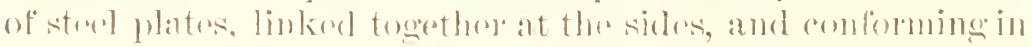

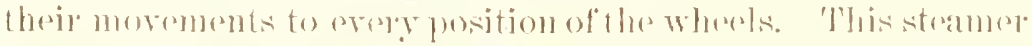
rould bo turnod in its own loweth, and mover itsolf about like at thing of life. So tram of loorses comld haveturned, backed. and stopped, with mole facility and eretainty. It was rennul, the stere hridgeway of a bann, having an elevation of ond forot

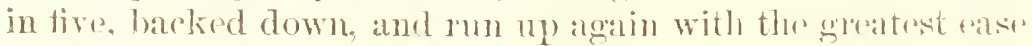
and farility. Hor a further confirmation of its ear)acity. a 
couple of lansere firm wagons were coupled belind it. in whish about twenty of thre guests were seaterl, for a lide. It trotted oft with ns, on the pnblic road towards Bristol, at the rate of six to seren miles jer hour, went through gates, tumed in at: bars, ("lossed soft gullies, went up shar p) hillocks, crosion at is sharp eleration the railsoad track, and clown again on thas othor side, and making a short turn. hromght ws hack thongen a field of fifty aceres. which had hesen plowed with it, to thes place of departure. This plowing wals beantifully done. arst

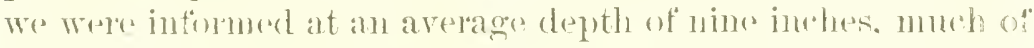

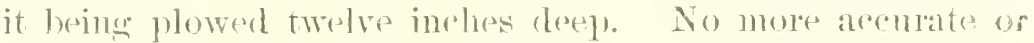
level fmums as it appearerl to us. rould be made by any plowman with a well-trained team of louses. 'Two of 1). LanAretlis sons accompanied the excursion party, and pointes! out the plowing in ditferent plares, performed by the stramer.

A fiter being mocompled from the wagons, it was attached for a trial of plowing to the Williamson Gang Plow, consisting of fiv plows, secmed to me frame. This latter so light, strong, and handy is the result of three years' hard work, much patienos and expense. It is made to contain six hard steel plows, each "utting a furow twelve inches wide, and, as I). Landreth informed the enmp any, had on one occasion plowed fomten inches depl). 'The ordinary depth the steam ylow has been worked at Bloomsdale is right inchos. On the way to the fiedd the plows followed the steamer as readily as a two-wheered ralt. Not a moment was lost in getting to work. The tield selectrol was an old tough sod, with a sterp gade in the centro. The tripping of a lever by the fireman, which he perfromed from his station at the boiler, let the plows into the ground, amb away rolled the steamer as straight as an arow. with the fough son fintows rolling over behind, like so many wates. Tho work seened jerfect, each furrow being mochandcally conlext, and alike in width and depth. At the aseont of the glade in the niddle of the field, no diminished sperel was observalole, the power seeming so ar hitrary and irresistible, that no ordinary field obstructions rould hare lesisted its continuons progress. Arrived at the end of the field, the fireman pulled another lope, and out shot each one of the plows. the steamer spun around on one wheel, lan across the headland. and tuming into a new land, was instantly at work on the rotmo bout.' 'Where was no hitch, no sliphing or hacking, but a simple, silent triumph of good, semsible snginerring.

We are thus particular in describing exactly what we saw. 
and was witnessed with surprise and pleasure by the whole company-because it demonstrated that the experiment of steam on the farm and on the road was successful in every point. Coming at a time when the farming business is unprofitable, and requires reconstruction, this new invention will greatly supersede in some sertions the labor of men and horses, will make more thorough plowing and tillage, and wiil increase profits, by economizing time and labor. On a large farm of tive hundred acres, like I. Landreth's, where there are no inside fences, it must he an invahuable addition to the working foree. 'The system pursued at Bloomsdale is one of high forming, the land being $l e p t$ in good heart, and ready to reterpu sixty or a hundred fold. or whaterer else is asked of it. The rapidly removing one cropand speedy putting in another, so as to secolle the whole growing season, is an important operation, which ean be rasily performed by the Williamson Steamer. but is slow and expensive by single teams of horses. Or our small firms around Philadelphia, clogget np with supertuous fencing. it is not expected or at all probable that single famers will buy one of these steamers: but they transport themselves, and may be purhased by individnals, who wil] go around a neighborhood, as now, with horse-powers, and perform thrashing, ploughing, and rarious other farm work, at a lapid and (heap late. The heavy drmand will donbtless be from the Wrest, where furons are plowed many miles long. They would also do adminably in the state of belawate, where farms are larger than here.

At the conchusion of a most bountiful dinner repast, D. I). Writhanson of New York, the inventor, by invitation, gave a brief listory of his stam plow, claiming for it not the extravanant powers which enthusiasts were wont to demand for their inventions, but that with good management, on ground suited to steam enltivation, it would plow from one to three acres per hour. according to depth of the furrow, and length of the lamd. The cost of steamer and plow complete, is $\$ 5,000$, as against $\$ 10,(000$, the cost of the cumbrous English system. 'The eonsumption of coal is about one ton pere day in both systems. In addition to the wages of an engineer and firemain, the Amerixan machine requires only a boy to drive a water rirt, while the Britisl tackle rmploys five to sis persons. The acreage plowed is about the same in both systems.

'The IVilliamson steamer is fitted so as to drive thrashing or other machines, and will haul from twenty to thirty tons of 
freight in wagons, on any fair country road, in gool condition. As regards compression of the soil in passing over, I. Landreth has carefully examined this point, and lias found that owing to these plastic wheels, no injury or undue empunession is efterted. We consider great credit is the to him and his sons, for thus inaugurating the use of steam power on the farm and common road, and demonstrating by prattical experiments on the field of Bloomsdale, its adaptation to the uses of the American farmer.

[From the "Germantown Telegraph," Philadelimia, November, 20, 1872. .]

\section{STFAM PIOWING AT HIOOMSDALE.}

'The trial of the Williamson Locomotive for road and field purposes "ame oft at the splendid estate of the Messr's. Tandwhi, on Fliday the 8th, instead of 'Jhmsday the fth, the day bring changed on accomt of the weather. We have sereral printed reports and communications of the trial, hwing anavoidably ahsent onlselves on this interesting occasion. W W have, however, witnessed several similar trials of plowing by stram, the first being somewhere about twelve years ago. Still, we should have been pleased to wituess this trial, which was more complete and varied than the others. Tartion stram-powe in plowing is by no means new, either in this comntry or in Enope, especially in England; bnt it lats bes n somewhat supplanted by the anchor-power, statiomed at the headlands, which we have so often rofered to in these (oll1mms.

The Milliamson-'Thompson Locomotive, as it is ralled, from hring the joint product of these two gentlemen, the former an American, and the latter, we believe, a Scotchman, posseseses sereal permliarities in its construction with a view to contract the size, yet retain its power, and enable it to bs assily hameted anct tmmed, not to be fommd in the others. which are of considerable importance to its permanent working. In the wherls, especially, there are many decidect inprovements, the principal ones being the use of India-lunber in sections, which, forming the rims, (anse the weight of the "ngine to pass over the gromed evenly. Nuch of the nachin. ery is concealed, aud is somewhat complicated, bnt not liabs to gist ont of oldere. 
It was first used as a road motor, drawing two farm waysans, loaded with interested spectators, on the publis highways, rossing a lailroad, ascending comsiderable elerations, :and tuming around in a common lane. Aloont two miles were thus traversed. hut there wele other sxperiments inthalged in, such as ruming up the ardiage-way to the bant, stopping half way, and starting up again, rite. "These showed that the locomotive possessed the power to oremome aserents. [t was also rum ore] a plowed fiedd, through puddles of water, ats... the construction of the wheels preventing undue sinking. A:I these exrellent foatures in this locomotion. Wo have orel in rat over read of in the previous trials of it, and liad non dombt thesl that they were correct as they are now poren to he. In fut we saw one of the locomotives last wese on onl way to Sew Yolk, used as a rivel to the horse reilways. in ralrying passengers. 'This, if we remenber rightly, was at Elizaluth.

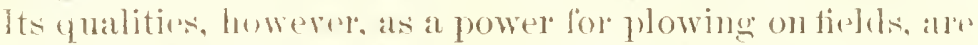

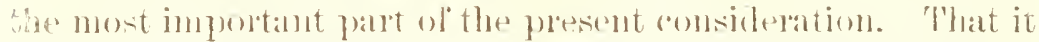

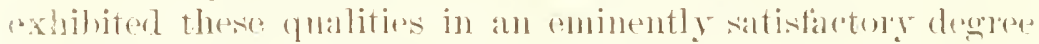

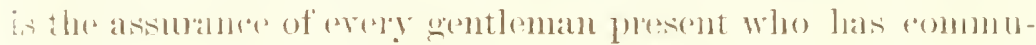

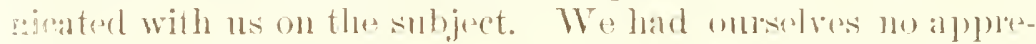
indusin of this befoue the trial took place, and wr so distinetly

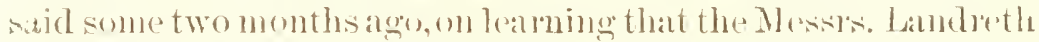

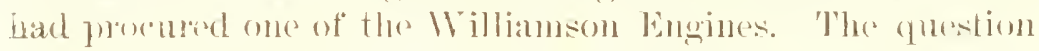

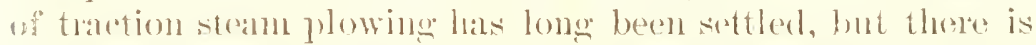
atgother question which has not beren, which we shall bristly

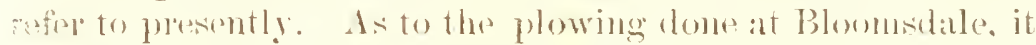
was woll dome, and as pelfectly as by hamb-plowing. Five

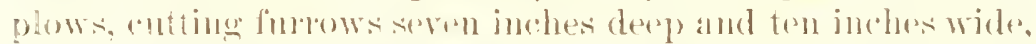

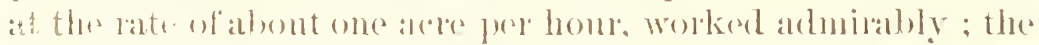

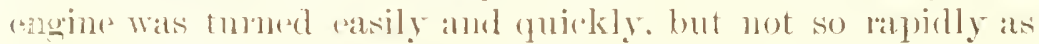

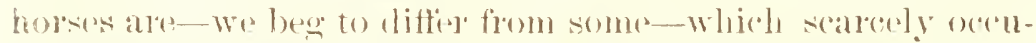

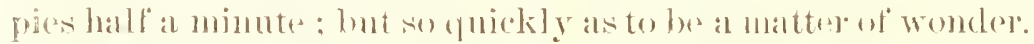
A statement made on the oceasion that there aleres an home an be arecomplished, is of rourse umworthy of a thonght. In

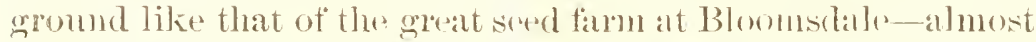
levol, a silndy root loam, constantly worked and mamumed, withont a stump), a roat, or a stome - at stam plow revels in a paradise, and and doubtless be used thele. mot anly to perfertion, but with profit: with profit, becamse it is hardly a question there of dollals and cents to get the work dome in the.

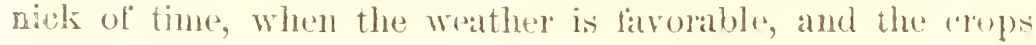
waght to be in. 
In England, the average work of a steam plow prer daty is from eight to ten acres-that is where stean plows are used, and their nse is far more limitrol there than is commonly be lieved. Here the work of the IVilliamson will be about the same, but say the highest number, ten acres. In support of this we quote the following from a private note of $\mathrm{Mr}$. Landreth, senior, who is one of our life long and bost beloved friends, and we take the liberty of doing so lecause what he says is of public interest, and can be perfectly relied on :

"I thin $\hat{h}$ we have solved at Bloomsiale the prothlem of plowing by direct traction, so far as light, level, friable land is concermed. I speak only of such-beyond that our experience does not extend, and I desire not to misload otlers. IV can readily plow an ace an hour, and while I write these lines I have within sight the TViliamson-Thomson Ensime, with five plows attached, turning over a pretty stiff sod at that rate, and ruming as steadily as did in olden times the ('onestogat Wagron."

But the main point for consideration, after all, is that of Eovnony. Ot this nothing is said, and indeed nothing need be said, so far as it refers to the employment of this power by the Messis. Landreth. As a point for the reneral farmer, howerer, or even of the most extensive farmers of the West and South-west, it is one of controlling importance. So far the reonomical question has been the death hlow of formur steam naction plows, and nutil that is settled satisfactorily, and on the right side of the balance sheet, steam as a motor for plowing will be restricted to partionala cases.

|From Georee Bugitr, Exq., a Well-known and Practical Faimer in Pennsyluame, November 20, 18\%2.]

\section{PLOIVING HY STHAM.}

() the invitation of Mr. David Landreth, a number of gentemen assembler at Bloomsdale, near Bristol, Penusylvania, to witness an exhibition of plowing by steam. 'Those pres"nt were derply interested in agriculture, and the applieation of stean to the cultivation of thesoil. They hat heretofore seen the performances of other plows in the vicinity of Philadelphia, 
and while they sympathized with the inventors, they felt that much more was to be done before any practical resnlts would be obtained.

On this oreasion Mr. Williamsom exhibited a " steamer," capable of performing not only the plowing, but the heary hauling of the farm. Two hay wagons were attached, and the visitors were taken over the large estate of Mr. Lambleth, and then on the main road, travelling at the rate of about seren miles per hour.

The plowing was rqually suecessful. A thoremgh trial was given on that day, and also during the past month, some. fifty acres laving been turmed orer at the rate of ons? acre per hour.

Your correspondent will atfrumpt no description of the plow-lis part is simply to ehomicle its sueress. All present were manimous in their aploroval of the work done, and rejoired in this new era in the progress of agriculture.

[From the "Gemantown Damly (imonicle," Philaditima, November 11, 18\%2.]

-TTHAM TIRAC"IION.

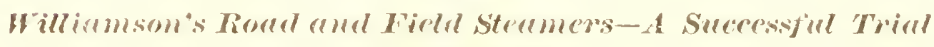
at Btonmsolute.

Tr is a hatply comedolences, that while we aro threatened with tho loss of on holse-powere a patriotic gentleman lass applied his large means and talunts to the apjolication of steam as a motive and traction power for the roal and plow. The English have amployed an infroriol invention for some time; as long ago as 1854 there Were, in Great Britain, nins

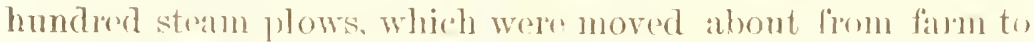
farm in some cases, whilo in others, individuats ane possessed of sufticient land to own one of thejr own. 'Thre names of' Fowler and Howald are farmhold wouls ju Fugland. In this combery, where the land to bre cultivated is often less level and free from obstrution, this mode of braking up the gromud has not been till now a gleat sureoss. The expense of a machine. and the eduration to wolk it, have bormolstacles ; but

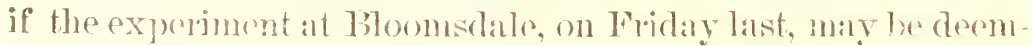
ed a smecess, as wo simcorely think it may, a most important. 
labor saving machine has been introdnced. Bloomsdale, however, is somm what exreptionally a convenient and level spot for the trial, with six hundred acres, and no feneing, except the bomndaries.

A number of gentlemen assembled by invitation at Mr. Landretly's sepd farm, near Bristol, Pemmsylvallia, and were invited to see the monster plow. Stean was nu, and the engine exhibited to great advantage as a roadstert. It turns in as short a radius as the most modern carriage, rums up an incline with great ease, and is under complete control by the managrment of two men. It was attached to two hay wagons, in which twenty-fonr men took seâts, and ware conveyed on an excursion over the large premises. At one time it swept through an open gate, bringing its attaches through with great accuraey. A locomotive, with a train from New York, ame along, when the passengers, secing the stranger waiting to cross the trak which it soon did. and ran up the incline to the road, rheered the invention vociferonsly. The party expressed themselves greatly pleased with the excursion, and no less with the beanty and order of the seed-growing.

The $n$ H W traction engine was quickly harnessed to a huge plow, and taknu to a five acre lot in deep sod, that had not been broken "1) for years.

It rapidly went to work, turning up fire drep furrows with the greatest ease, and was pronounced by all a trimmph. It is capable of plowing one arre per homr, as much as a nsmil day's work with horses, and may thus get throngh in a perfect manner, ten to twelve acres in a working day. The Thumson patent wheel, greatly improred by Williamson, ingenionsly constructed so as to give a long impact or tonch to the earth, is the great secret of this invention. The indir-rubher is made into the form of cans for fruit, with strips for a gman, and the weight of the machine rests npon these, thoy givo way slightly, and the greater contact impringes on the rarth or sod sufficiently to gain traction power. There is no injurious compression of the soil, the great bearing snrfies of the rubber tires distributing the weight of the steamer so as not to exeed the pressure of the hool of an ordinary horse. The steamer steers perfectly woll, and can tum at the end of the field as quickly, and in as little space as horses. Fly whel and governor are attached, with which to drive thrashing machines, cotton gins, or other stationary machinery. The angine used was the eight horse (nominal) road 
steamer ; the plows are of the best steel, and are amanged to plow from one to nine inches deep. A gang of six breaking plows, each antting fourtern inches wide, costs, with steamer and stationary gear complete, $\$ 5,500$ net, and will lneak, if required, even two acres per hour of rmming time, with the ground in good condition. With a rigid bean it will plow eight inches deep, at the same rate of speed and cost as above. In some sections a seeder and harrow can be attarehed, and thus complete the field work in one operation. No additional help is required in plowing, beyond that of the engineer and fireman, as the latter also attends to the plows.

With heary work a consumption of three pounds of soft enal is required, the extrenes being from two to four pounds of coal per mile for each ton of gross load on common roads. The consumption of water' will be about serem pounds (three and a half quartsi) for each pomud of coal romsmoned.

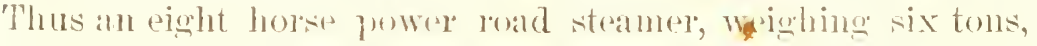
drawing a loat of eighteren toms, making a total wojght to be

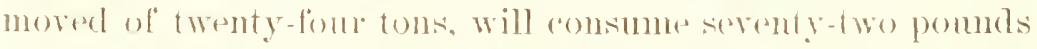
of coal pure mile on good level roads; say halla tom of coal por day"s work of ten hours. The machine has hunleres for a

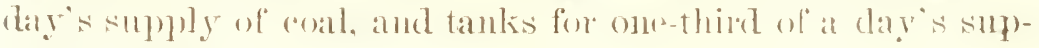
ply of water.

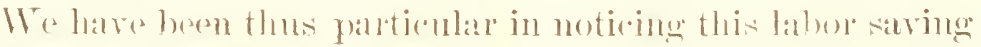
alplaratus, becamse it is likely at no futme day, and with probably of here inpmorements and simplitieations. to be one: of the farmeres sherished labor saving applications of ingemeity, thought and sill. It will not have the rapid introduction that the rateres had, and probably will be owed by parties who will take it romed and plow for a neighborluesed, at at given sum pere arese. It works so rapidly that it will ancommodate a mumber of fimmers at the season when most rephined, and all know the great advantage of breaking nje the grond in the fall seatson, and leaving it to the nomrishment and disintegration of winter frosts. A grood business may be reated by at moderate expenditmre.

We camot elose onr bref notice without a word on the sreat Landreth seed farm. In extent and importinues it has no rival at home or abroat; it is managed with business taret of a high order, and with experience that it has taken at least fifty years to perfect. The kindness and liberality of the owner are nowhere exereded. In short. Bloomstale seed farm is a model of completeness and usefulness beyond praise. 
No English gentleman can be more justly promd of his acres than Mr. Iandreah, and in the useful molpoyment of his talents and money, we know no one to be more envied. One would suppose twenty acres would raise all the sechts required, but here are six hundred, and the product is carred to the East and West Indies, and even to Europer, and theres is never an overplus.

[From the "Bucks County Intelligencer," Noremieis 12, 187.2]

TRIAI, OF A STHAM T'IOW.

An Interesting Day at Bloomsdale.

The ajplication of steam to agricultural purposes, especially to the work of plowing, has hitherto reeeived much less attention in the United states than in Europe. On the farms in England some three thousant steam plows are in operation. while in this comntry, with its great facilitios for using them, particularly on the great plains of the west, there are probably less than at dozen of these implements employet. This is dombtless in a measure owing to the great cost of those in use in Great Britain, which, up to a recent period, have been the only kind of steam apparatus adapted to this branch of farming. Plowing by stram in Englant, as is known by those whose attention has been directed to the snbject, is done by a stationary engine, placel on the side of the field, by which the plows are operated, by using long wire ropes. At tirst, only one engine was uset, but it was soon found necessaly to have two, stationet on opposite sides of the field, the plows to be run by a complication of machinery, ant the wire ropes already mentioned. 'This method was so fal flom satisfarctory, that the inventive powers of those interested in the matter were set to work to derise a plan by which a steamer conld be eomstructed that, instrald of remaining at a fixed point, could be moved across the field, drawing the plow alter it. "To accomplish this the matin object was to construet wheels on which to rum the engine, of such at chatater that thry would adhere to the ground sufficiently, and at the same time not sink much below the surface. This much desired end, it is believed, has been achit'red by the employment of india-rub- 
ber in making the rims of the wheels. It remained for an Amorican inventor, D. D. Williamson, of New York, to make, a practical application of this discovery in the shape of a steamer for plowing in the manner last described, and for which lre lias obtained a patent. Abont two months ago David Tandreth \& Son, proprietors of the great seed fiam at Bloomsdale, near Bristol, lad two of Mr. Williamson's Steamers brought to their place, for the prrpose of testing them. 'The Messis. Tandretli are well known as liberal patroms of every improvement calculated to advance the interests of agriculture, and they have therefore exerted themselves very diligently in testing the merits and eapacity of $\mathrm{Mr}$. Willianson's invention, not only fol theix own and the inventor's satisfaction and advantage, but for the benefit of the farming intelests in the country generally. 'They have plowed abont fifty acres of gromel upon their farm with these machines, and so well werer they satisfied with them, that it was decided to give a nor's publis exhibition of their operation.

Accordingly, on Friday last, by invitation of the Messls. Landroth, a number of frominent persons interested in agricultural progress, from Philalolphia. Baltimore, New York, Boston, and other places, assembler at Blomsdale, for the purpose of examining the workings of this great invention, which serems destined to bring aloont a revolution in farming in the Cnited States. 'Tle company. inchuding mamy porsons who had never visited Blommstale before, spent some time in inspecting the buildings, and other objeressof interest about the premises, and then gathered to "xamine the stramere, which was fired up', and in order for use. 'The general construction of the steamer is similar to that of ordinary portable engines, the chief points of distinction boing the style of the wheels, and additional apparatus for tuming them aromot. One of then has four whose, tho two in fiont, which are used to guide the steamer, bring much nalrower and smaller than the two hind ones, the lims of which are abont eighteen inclies in width. The front wheels, mpon which there is a much lighter weight, aro only half that sizs. Betwern the inner and onter surfaces of the rims of the wheels are placed a series of sections or blocks of india-rubbrr, fom inches in thickness, throngly which metallic bolts are easily passed. These rum through a series of iron plates, three inchess wide, and an inch in thickness, which are placed a short distance apart, alud 
form the ontside surface or tire. By this arrangement the weight of the engine compresses the india-rubler, a large surface of the wheel comes in contact with the ground, the weight of the machino is distribated over a much larger portion of the ground than it ean be by any other known means, and the inessme at any point, therefore, does not much exceed that produced by the hoot of an alverage horse. The other is a three wheeled steamer, the guide wheel being immediately in front. Another, and the principal point of distinction between it and the other is, that the india-rubber used in the construction of the wheels, instead of being in sections, is a continuous band around the wheol. Mr. Williamson does not think this as good a plan as to have it in sactions.

The risitors were first shown the locomotive powers of the steamers. They are pertectly manageable, cren in the hands of enginesers of limited experience. They can be readily and quickly stopled, either on the level or in ascending a hill. By an ingenious attachment ome wheel is made to stand still, while the other moves, so that they can be turned around with perfect ease. Their forward movement is readily chereded, and they can be backed with facility. Their movements in this particular excited universal admiration. The next step in the programme was to exhibit theji adaptation to the purposes of hamling or carriage over our common wagon roads. For this purpose a train, consisting of two heavy farm wagons, was rigged up. These wero provided with seats, and the train was attached to the rear of the engine. The seats were soon filled with a portion of the company, and when all were realy the signal was giren, and the train moved off. Starting at the center of the farm, near the buildings, it passed throngh an ordinary wagon-way. ont to the turnpikn, ovel ground both hard and yielding, and surface rough, as well as eren, up hill and down, the engine puffing and snorting along to the astonishment of the people, who ran from their houses, and from their work in the fields, to galze at the nowel spectacle. Leaving the turmpike at the road bounding the Blommsdale farms on the east, the proession passed on northward, in the direction of the Philadehplia and 'l'renton Railroad, which was approached just as an express train passed by. The passenger's caught sight of the formidable train, and from joy at having escaped being demolished by it, or from dolight at the dawn of the new era in the age of steam, the windows tlew open, 
and hats and handkerchiefs came forth in large numbers, which salute was returned by the Bloomsdale party, who, by this time, were in ecstacies over the snccess of this new experiment in railroading. The train now erossed the railroad, up a sterp embankment, and passing around abont half of the firm, turning several comers, throngh narrow passages snccessfinlly, going over around in miny platees decisledly yielding, from the effects of recent rains, returned at last to the place of starting safe and souncl. The distance travelled was over two miles. and the rate of sped about six miles an hour. Those who enjoyed that ride will not soon forget their first experience at railuading, noder the new dispensation.

The next and most imprortant giart of the exhibition was the plow trial. 'This test was mate moler somewhat unfirorablus eirenmstanees. Owing to the heary mins during the middle of the week, the gromeds on the firm were too wet for a fair test of the machine. It was, howerer, decided to make the trial in a piece of sod gronnd, although the plow was not riegred for that purpose, having no roulters attached. The one that was used on the occasion consists of a series of six plows. These plows are made of steel, and are attarehed to a heary wooden beam. to which two shaftes are aflixerl. The beane lums obliquely with the shafts, by which the plows. when in motion, just precede each other in tmrning up the arth. On this trial it was thought best to take ofl" one of the plows, and nse hut five. The plows "an be ron any desired depth, from six to ten inches, this being lexgulatod by quarlrants attarled to the frane. Whell all was ready, the frame work of the plow was attached to the lear of the stramer. hy a fravy ehain, and the machine, wnder the charge of the encineereand fireman, was put in motion. The ground chosen for the trial was covered with a rather stift sorl, but the soil was drep and loose below, and with all the variety of surface for in thorongh test of plowing, both on the level, and up and down hill. The plows entered the ground promptly at the bidding of the fireman, who, in addition to his other duty, had charge of the apluatus for this purpose, as well ats for lifting them out of the gronud at the other end. It plowed a. uniform depth of abont seren inches, each fiurow being turned over as nicely as if done by an experienced plowman, in the usual way. At the end, the plows were taken from the ground quickly and easily, and the tmrning of the steamer 
and plows to enter fresh furrows on the other side of the enclosme, was done as speedily, and with as much fucility, as with an orelinary pair of horses. The plow was rme at different degreses of spexd, from that of a common plow tram, to clomble that rate. By inereasing the rate of sprest, the gromme is pretty thoromglily tom to pieces, and we shomld think that were it sufficiently dry, and in good order, it would not need much larrowing aftrwats. Fach plow makes a furpow a little orel a foot in winth, the whole five at a swerp plowing a space of six feet. Thlen all six of the plows are attaleherl. it tmans mp a suace of a little orer seven feret wide. The work was done so well that the trial was sucessful, even beyond the expectation of the inventor, who was present, and all others who witnessed it. By rmming at a moderate rate of speed. it will readily plow an acre an lomr. This is about the average of the work that has been done by the plow at Blommsdale. But this is by no means the limit of its capacity. Mrr. MVillianson had a letter from a party in the IVost, to whom he had sold ons of the machines, in which it was stated that it had plowed as moch as three acres of prairio land an homr. The price of the two steamers, respertively, is $\$ 4,500$ and $\$ 5,000$. The company present at the trial on Firialy, was composed of intelligront men, many of then of lango experionce in agrinttural matters, and others of rxtensive seientitic attaimments. and skilled in machinery, and they wepe nuited in the opinion that the aflair was a grand suceess. It was comblmbed that the steam plow is a fixed fact, and that if the invention has not yet reached perfection, it has approacher so neal it as to warant the prediction that a great revolution in the "ulture of the soil is at hand, the importaner of which it is impossible to estimate.

After the trial was orer, the aompany letwrned to the fine mansion of Mr. Landreth, when the hospitalities of the propritor wero dispensed with his nsmal liberality. Thesplendid dimner provided for the gursts areorded well with the importance of the oreasion, which may yet prove an epoch in onr agricultural history, of more moment than the most sangnine friends of proglesi now anticipate. It the close, the plow. the plow-make', and Mossts. Landreth \& soms, wore toasted, and specehes, abonnding in wit. pleasantry, and general good fexhing, were mate by Gen. Patterson, Dr. Emerson, J. I. Smith, of Philadolphia; Prof: Wilkinsom, of Baltimore; R. Morris Copelaud, of Boston: Mr. Willianson, and others. 
Thus ended one of the most interesting and pleasant gatherings in the experience of those who enjoyed it, and one that will be remembered in the future among the most happy recollections of their lives.

[From the "Jounval of the Farm," Pmiladelphla, December, 1872.]

\section{WILLIAMGON'S ROAD ANI, FIELD STEAMETR.}

\section{Roal und Field Steamer Trial.}

Trus absolute necessity of introducing to wneral use, or

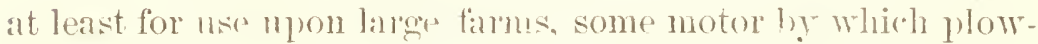
ing, lleary hanling. Ete., can fue dome more realily and more cheaply than by horse or mule. or ox power, is luesinuing to he recognized in this comutry. In England, the sul juct las berm discussed at lemgth, and the practical rosultis an sorn in the use on many buglish fams, of steam plows. Latforly, roan and field stramess havo been introduced into the lnitud states, and we had an ofportunity of witnessing flesio operation a few weeks since, at Bloomsdale, on the famm of T)arid laundreth of som. He are prepared to indorse their stromg saims to popritar for form.

About two months sinee, Messes. Jandretlo \& Som had two of these improvere steamers brought to their famm, at blomisdale, for the purpose of giving them at thorough, puretiral trial. Altor laving plowed some filty aroes with them. they wereso well satisfied of their value, hat a public axhilition of the machino at work was agered njom, and in ("onluthy with a

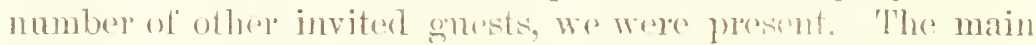
feature of the megine is the peenliar charatefor of like wheels. This is the inrention of Mr. I). D). Williamson, of New York. Lacking space tor a minnte description of these wherels, we must content omselves with brivfly stating that the rims, or tires, are made of india-rubber, which, being wastic, suflicient adhesion is ohtainod hy the driving-whers, withomt damager

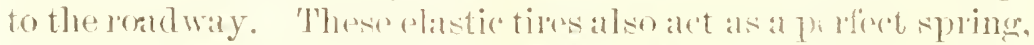

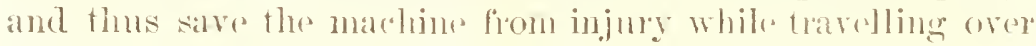
pough smefices. The gimeral comstruction of the strimer in other respects is like that of ordinaty portable engines.

'The locomotive power of the stuaners was first exhibited 
to the visitors. They were shown to be perfectly manageable, whether on an ascent or descent. 'Two heavy farm wagons, provided with sats, were attached to one of the engines. The seats were fillol with a portion of the company, and the train started-passing over hard, as well as yielding gromnd, rough as well as smooth. Steep embankments were ascenderl, short rnrves tumed, and after travelling for at least two miles, at a speed of six niles per hom, the starting point was again reached.

The nost important part of the exhibition was the plow trial. The gromul chosen was a stifl sod, with a deep loose soil below. The plow used consisted of a series of six plows, one of which was taken oft. IT e have not space to describe the construction of the plow, reserving that for another occasion. The plow can be rum to any desired depth. It is attached to the engine by a strong chain, and is managed by the fireman, who not only regulates the depth, but operates the apparatus for lifting it-or them, rather-out of the ground. at the end of the field. This latter operation is as quickly and asily performed as is the lifting and turning of a single plow, with horses attached. Each plow makes a furow of a little over a foot in width, the firw turning up a space of abont six f'ect. The depth was miformly seven inches, and when the oldinary horse speed was alopted, the finrows were evenly laid, but the rate was dombled, and then the soil was so thoronghly disintegrated as searcely to requiro harrowing. Rumuing at a moderate spered, it will nlow an acre an hour, but this speed can be increased at will.

After the rery satisfactory exhibition of the calucities of the engines and plow, the company returned to the fine mansion of Mr. Landreth, where they were most hospitably entertained. IVt regret that want of space compels ns to give so brief a description of the ploasant occasion.

[From The "Ledger and Transcript," Philadelpila, Dec. 19, 18\%2.]

STEAMT ROAD WVAGONS AND PLOWE.

IN esteemral correspondent sends us the following account of the performances of Williamson's Common Road steamer, for the propulsion of wargons, and for field service on 
farms. The exhibition of the steamers was recently given at Mr. D. Landreth's seed farm, Bloomsdale, near Bristol. Our correspondent writes as follows:- "The steamer adapted to common roads, liad two fam wagons attached, with twentyfom persons in them. Starting with this train, it passed down a lane, through a gate, took the public roal, turned into byroads, and after a run of two or three miles, at a livoly ratr. resmoned to the place from whence it set out. The stemmer is

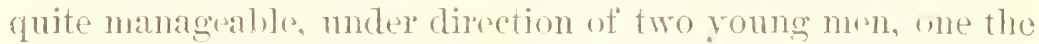
conductor, and the other a fireman. It turned in a vry small space, and sermed as easily controlled as a velocipede. Its hanling capacity is fiom fiftern to twenty tons, and hills of modruate grades are readily passed over. In carrying passengers on a good roar, it is clatimed that a speed of twolve miles jer honr may be made. In plowing. or other heary work, thes sporal does not exceed four miles ner hour.

"On Mr. Landreth's great seed fiarm of five hundrod acres, withont inside fonces, and in higl culture, about fifty acres had been tmmed np in an almirable manmer, to a depth varying from serento nine inches. 'T'o afford his visitors an opportmuity of soring the manhinery work, Mr. Tandreth latd it turmed into a fursh fired of simf raly sod. Thromgh this it

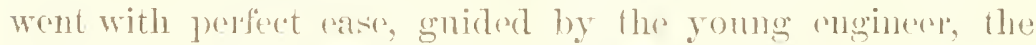
firomaln sotting in the ganger of polows, and raising them at the end of the gows. The tuming was areomplisled in from thinty to fifty seeomels, by a watele. The gang of piows roul-

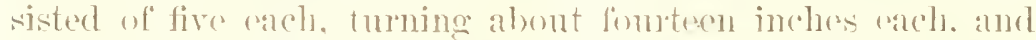
altogether a wilth of six fect. 1 sixtle plow can be fixed to the hram, but with five plows nowly an arese an hour can the readily turnod, of about eight acres per day, with due allowance fis jumerliment.

"The main principle mpon which this steamer dejends for" its sureess orre all others, is a peculiar construction of its whores, rnabling these, in their rotition, to take a stromg hold on the gromud, so that nearly all the power of the engine is expender in traction or propulsion. 'The tires of the wherels are nuade of "lastic unbber, of pxtraorinary thickness. Tpom the circumference sterl plates are attached, about a fort long, thror-quarter's of an inch thick, and an inch apart, making the fare of the whers one foot wirke. On coming ripon the gromnd, these broad, lastic wheets yielding to the pressure rpon their lims, take a strong hold. The weight of the engine is so distributed upon the broad wheels that these cause no 
greater impact upon the ground than that ordinarily made by the hoofs of horses. The rubber ties operate as springs, and obviate the effects of concussion. 'These steamer's-rated nominally of about cight horse power-with the gang of sted plows, cost abont $\$ 5,000$. A fair estimate of their value must he based upon the amount of work they are capable of doing, and time saved. These machines can he smployed not only in breaking up ground, and preparing for mops in litte time and in the best manner, but in reaping crops, thrashing the grain, hanling it to market, and doing other things to which steam nower is adapted."

[From the "Boston DAILY Advertiser."]

PFINNSTIVANIA.

The Farms of David Landreth and his Sons.-A Now Steam Plow and Traction Engine.-Hodem Improrements in Faming.

[HROM AN OCOASIONAL CORRESTONDENT.]

I RECEIVED recently an invitation to go to Bloomsdale, at Bristol, on the line of the New York and Philadelphia road, the home and farm of David Landreth, the great seed-grower, to witness an exhibition of a new steam plow and traction engine. Tre have carried the improvement of some kinds of agricultural machinery so far that no great improvement in the method of harresting crons are likely to be made. Alterations in methods and machines will follow their use, but no radical change is to bo expected which can affect the crop of the conntry. But an improvement in plowing, which will give a man the same control of the preparation of his land that the mower or reaper has orer his ripe crop, would be of incalculable advantage. There are two short seasoms-one in the fall, the other in the spring-for plowing, and on the good use of these two periods depends the amount of every crop. A few days of lain, or of cold, wet weather, that prevents the hot spring sun evalporating the water from the saturated earth, may reduce the rrop very largely. An arerage team can plow an acre of average land seven inches deep in a day. If a man has a hundred acres to plow and seed, it will take ten teams ten days, and all the chances of weatler, 
the cost being forty dollars a day at least, or four dollars per acre. If he conld plow the land with one machine in ten days, at about two dollar's per arre, and do his work better, there would be reason to believe that a man could get rich by farming. Now, better than this can be done. * * *

Abont twenty-fire years ago Mr. David Landreth. the head of the present firm, bonght the firm of five hundred arres, which he now occupies at Bristol, having a long river front, permitting all mannies and heary freight to be landerd at his wharf, and bateked by the canal, and by the railroad. The land was a sindy soil, easy to cultivate, and easily dried after rains, but was wreteledly poor. He and his sons began their work with vigor, and to-day the five hundred acres, the huge barns, seed-rooms. wallellonses, lawns decorated with the most beantiful tress and shrubs, the dwelling-honse, whichl was an old farm-honse, which has now hlossomed out with dormers and gables, and is shaded with hoad piazzas, and clatd with lexmiant vines, make a pieture and tout ensemble not equalled anywhere else in this romntry. These five hundred acres are

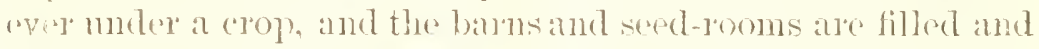
ampetiol live to seren times each year with different seeds. (Jnee harvested, the plants that ale full of sem ale lamdled mostly by stram power-are raised and lowered, thrashed and wimnowel, dried and camped to their bins liy stean power-and atre then assorted and praked by nimble-fingered girls and boys, into the little and big packages familiar to om gardener's and finmers. Evergerop, when prepred, is divided inte two; one-half heing sent to the city warehouse, the other demaining or the farm, thus being secured from danger of total loss hy fire. Whate the grandfathere grew pounts of seed, these ment grow tons.

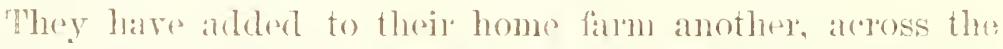
river, in Now Jorsey. They buy all their peas from Northern Now York famers, where, as yet, the weevil has not gone. Their potatoes are grewn in New England and New York, and their corn from Camada to Virginia.

At Blormsdalie, all the construetive and repairing work of the farm is done by thenselves: they have shops to make and refoir their tools, and when one looks at the stacks of torls, droves of plows, the flocks of harrows, the swarms of serelsowers. drills. and minor instruments of culture, lie might, think he was in an agricultural warehouse, rather than on a farm. It takes forty horses and mules, and an army of 
laborers, to produce and manage all the eropes. IIundreds of tons of guano, super-phosphate, bones, blook, oftil and night. soil, are landed each year on these farms, coming from all parts of the world, as well as the United states. and side by side you may see the hoofs, blood, and homes, of thr Chicago (attle-yard, and the cincimati slanghter-houses, and guano fiom the Chincha Island gramo beds.

Every toil-worn inventor knows low ham it is to find a good ehance to try his macline, esperially if a lirger one, and one which requires the co-operation of other men. Mr. Williamsom, the Ameriean patentere of the trastion engine, learned this to his cost, and tried long and firuitlessly to find a plare to experiment in steam plowing, until he met with Mr. Landretlu, who was not only ready to believe in and help forward a good invention, but eould open tields for stram culture that would fully test the power and value of any machine. I will not consmme space deseribing the machine itself, for that I will refer to the patentee, D. D. Williamson, B: Broadway, New York. The peculiarity of the engins is that it has at wide band of india-rubber, six inches thick, for the tire of its whecels-one engine has the rubber in a eontiunons ling, the other in sections; the rubber is faced with a lind of chain armor, whish keepls it from contart with, and wear on the carth. but the india-rubler spreads under the weight of the engine, and the fares or lim of the wheel seems to anen ont like the paw of the eat, wr the foot of an elephant. and gets great hoid on the gromel : and although the marhine weighs seren tons. its two wherels do not press sod gromen more than an inch deep, marking its passage orer fallow ground hy a path fourteen inches wide, and an inch and a halt derp. There is a third wheel, like a relocipede, which tums the engine, and it can tmoln round and round in its own length, making a poufort (aircle not more than fiftern feet in cliameter. Two wasgons. attached to the engine, and loaded with thirty people, stalted on a tour romed Mr. Latndretlis farm, sometimes on the road? sometines in fields, tmining the shimpest colners with ease. We were shown fiekds of ten and twenty acres, plowed with the engine, at a cost of $\$ 1$ per acre, and tru arowes al day. After we leturned to the house, the gang plow was attalchest to the engine. and we sturted for an old grats tield, correret with a strong sol. The plow had six momle boarels, or, as it were, six separate plows in one; the mathine storted at omes, and drew the plows $u 1$ and down the ficld, over somesterp 
grades, turning a furrow bed six feet wide, formteen inch fumows, seven inches deep, and moved as fast as a man conld walk. It tuned on the headlands in thinty seconds, and whether going up or down hill it conld be controlled, regulated, slowed or hastened at will. One of these plows, sold to a western raihoad. was put for a first trial into a Minmesota prairie, with an extremely hard, rooty sod. and was drirne as its first test, withont stopping, one mile in a straight line, conling orer mbroken funcows thirty and forty feret long. 'The fumows, as they follow the plow, break like the form crests of waves on the shore.

Thons you see the point I made at the heginning of my story in illnstrated at the and-tem andes an be plowed. I have said nothing of the value of the machine for general tratotion; the same engine ean liaul a string of walgons to a gravel bank, load them, with as stram shorel, talke them onit to be dumper, plow. mew, and reale, thask, drive piles-in shert, do all mis cellaneons work, and I hope will soon be so improved as ke do genoral honiswork.

… ‥ ('.

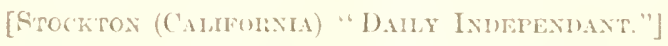

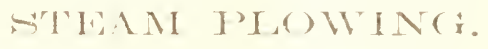

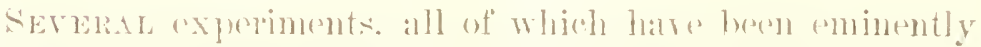

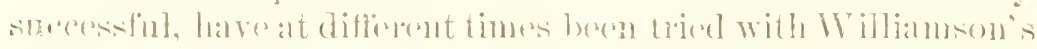

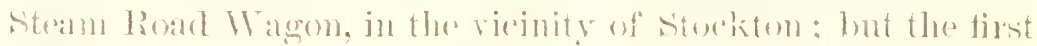

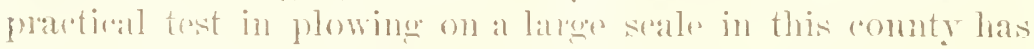

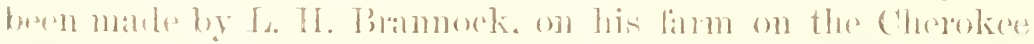

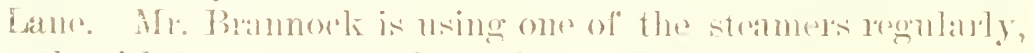
and, with two gralles of fom plows atel), plows fiom twonty-

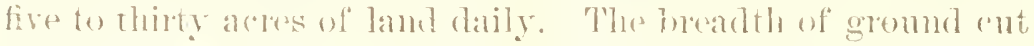

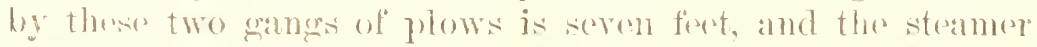
draws thrm alomg stualily and rapidly, without any difficulty whateres. 'The expenses of plowing in this mamere is fommet to be mureh less than by the ordinary mothod of using animals. No diffionlty whateres is experenend with the steaner on

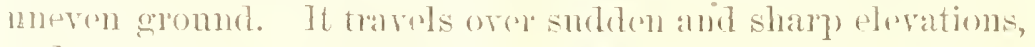

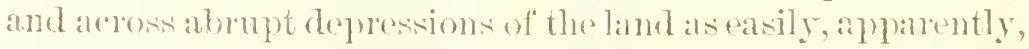
and with ats little interuption, as are its morements along a 
gravelled street or turnpike. One very great adrantage which the steamer possesses orer teams of hor'ses or oxen is, that in clearing land the steamer ean readily be detached from the plows, and fastened to a newly felled tree, which is bodily remored by the machine to any desined part of the field. In work of this kind the wonderful power of the steamer is shown eren better than in plowing. It will haul off a lange oak tree, trunk and branches together, with as little aplarent difienty as it woukl travel with a brush hamow. ITe are told that Mr. Bramnock, after having given the steamer a more extended and thorongh trial than it has herefofore latel in this section of the State, is woll satisfied with its working power, and its adaptalility to the heary labor necessary to be dons on a well managed firm.

At the California state Fair, held at Sacramento, a prize of Sio and diploma were awarded to the Williamson Steam Plow.

[Stockton (Califoria) "D.imy Independant,"]

WILLIAMGON'S IROAD WAGON.

This locomotive, for use on common roads, and on exhibition, under the charge of Mr. Barmaby, in this eity, hauled five wagons, loaded with glatel, from Mr. Orerhiser's farm yesterday. Mrr. Overhiser tells us that the gravel hauled inter stockton hy the locomotire. or steam wagon, at one trip, weighed not less than thirty tons. He belises that it ean haul sixty tons. An exhibition of its power in plowing will be given on the land of Hiram Fisher, on the east sirle of the city, at 20 clock next Satmrday afternoon.

[Extract fiom Tetter from Messrs. Camplent \& Turton, Sugar Planters, Laphania Maui, Hazadian. Istands.7

"The Williamson Road Engine, ordered by us through our agents, has arrived safery, and been carefully sut up. We have tried the machine, and find it works beantifully, and 
believe that it will do all that is required of it. We are much pleased with it. On good roads it will be invaluable as a substitute for cattle, as in this warm climate cattle will not stand the work. We hope you will hare more orders from on faroff Isles."

To D. D. Thlmamson, Esq., New Tork.

[Extract from a Telter from Clar\% TW. Thompson, Esq. President of the Minmesota simthern Raitroad, dutert Wells, Minnesote, October rth, 1872, ordering a duplicate part to replace a piece broken in his. Tritliamson Steamer.]

"Pluase have us a duplicate made as soon as possible. It is getting late in the season. and I lave three thousand ateres to plow yet, and we are losing thirty acesesery len hours. We will have to run here day and night."

The buaking plow used by Col. Thompson on his thiteden

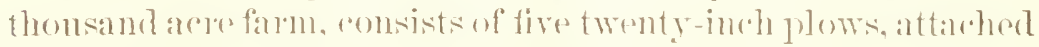
to a triangular farme. with arrangements for lifting ansel regulating the depth of the plows. Fath plow is seplatates and an be taken ont to be shanjened, which is aldsolutely neossary in braking virgin praire. At the first trial. the steaner drew this gang. plowing one humetred inches wite, and fome inches deep, in a straight line, for a distanee of ome mile and back. accomplishing the two miles in thirty-four minutes, the area plowerl being a tritle over two aceses.

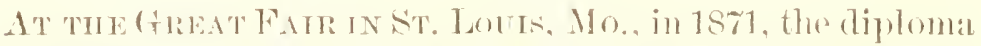
was awaded to the Williamson Roal Steamer and steam Plow. " for the most impurtant invention relating to agrienlture, patented within three yass."

This diploma had not been awaded for there years, as nothing exlibited hat loen considered worthy of this special honor. The plowing tone was one hundred insless wirle, and fom and a half inches drepe, and the speed thror miles per houl. The roal test was with a train of four wagons. loaded with one humdred and forty men, ant the speed was nine miles per hour. 


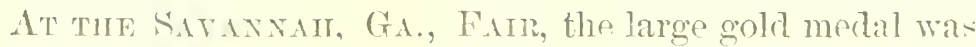
awarded to the Williamson Roar Steamer, (owned by the (reorgia Central Railroad.) The steamer had been employer? hanling loads, consisting of six logs in trucks, and doing the work of twenty-four mules, on deep sandy roads.

Mrr. John Yoyna, of Salt Lakn, Utan, writes: " I an perfectly satisfied with my road steamer. I consider the load she has been hauling equal to thirty tons on goot wagons."

'This steaner is now employed hauling silver ores over the monntains in Etah.

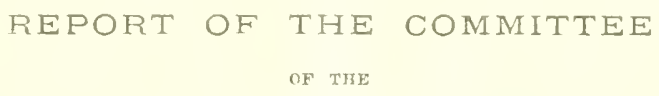

\section{WILAINGTON (NORTII CAROLINA) FAIR, 1581.}

AWARDING THE GOLD MEDAL TO THE

\section{WILLIAMSON ROAD STEAMER.}

The nndersigned committee, to whom was referred the above named machine, for a full report upon its merits and defects, respectfully report:

A full test of its capacity was made on the grounds of the Association, around the race track, and for abont three-fourthof a mile to and froover the conntry road, across one "branch," and ont of the road into the pine woods, up a declivity of abont one in five, and bark again into the fair grounds.

The rare track is built of a surface of clay abont two inclues thick, upon a berl of sand; a load attacherl to the steammr. romposed of a ten-horse engine, on whets, and four ordinary road wagons. loaded with people, which proved too much. on aceomit, as we beliere, of the softness of the track, and the narrow tires of the wagon wheels. With the engints alowe refered to (wright about six tons), the steamer moved readily around the track, and afterwards drew the four wagons, with full loak of people, masily. 
We understand the proprietors claim that on roads in ordinary good condition, that the steamer will draw in the wagons, with broad tread wheels adapted to the work, twelve tons dead weight. We beliere that this machine will come fully up to the elaim.

We further believe that in charge of competent mechanics, these steamers will be nseful and roonomical, as foeders to the railroads in this section of the state. and as a gool sultstilute for railnoads, where there is dificuly in pocuring calpital for the construetion of the latter?.

Withont load on the race talek, the steanner moved aromed, one-half mile in one minute and forty-eight seconds, or about seventeen miles to the hour.

The boiler works woll, furmishing all steam necessaly lor the heariest work.

With full loaded train, the spored will be aight miles an hour, win level road in gook oreher. The road is impored hy the steamer passing orere it.

In conchusion, we think the stramer capable of doing all that is elaimerl for it.

Water tanks are attatehed. with capareity to furmish water for six miles ron ; and bunker's for coal snlficient for half day"s

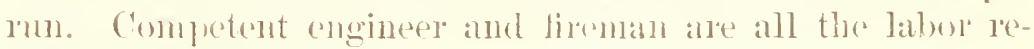
quiled for a full train.

the steaner is well adapted for duawing a gang of five twenty inch plows (or serens twelve inch), and we think will (1) well in this respert.

Arrangements are providal for nsing the power of the engines for driving cotton gins. thrashing matehines, or other

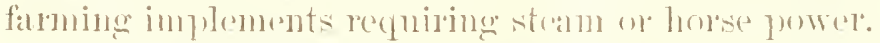

In consideration of the careat sureerse of this marhine, and its eminent ataptakility to work repuland in this section of the eountry, the committere resommend an awarl of the highest joreminum of the Association - the Gold Mfedal of the Association.

$$
\begin{aligned}
& \text { JNO. C. BAILLY, } \\
& \text { C. S. Selivoss, } \\
& \text { J. F. Finfier, } \\
& \text { JOHN BISSET, } \\
& \text { Wy. L. DeRonste, } \\
& \text { ArCir. PAE, } \\
& \text { Jome Cothriale, } \\
& \text { H. J. RISLEY, } \\
& \text { S. W. SkINNLit. }
\end{aligned}
$$


[TROM TIE "AIBANY ARGUS," JULY 18, 1872.]

\section{STHAM TOTVINT: ON CANATAS.}

The practicability of using steam as a means of towage mono camals, seemed to be fully demonstrated yesterday afternoon, on the sextion of the canal between lock No. 1 and the arsenal. The motive power used on the occasion was one of IVilliamson's Road Stramers, muder tlo pelsonal supelvision of the patentee, Mr. D. D. Willianson, of New rolk.

In order to give a correct idea of the working of this road stramer, it will he meressary briefiy to describu its working parts. The boiler is fixpd on the exoss piece of a pa shaped frame, which is nonuted on three rough iron wheels, having a band of india-pobber aromel them, four and a half inches thick, by twelve inches broad. The front, or steering wheel, is three feet in diamoter, with a twelve inch face, and the side wheel five feet in diampter, with fifteen inch face. The indiarinbluer band, or fice, on the mhers, is protecterl by a serjes of strel shields, one inell and a half apart, fastemed together by an sudless chain, which imbed themselves in the india-rubber facing, as the wherel passes over the ground. The propelling jow is obtained from an engine, consisting of two rylinders ton inclues long, and six inches in diameter, which, by moans of gear work, turn the side wheels either bickward or forware, at the pleasure of the engineer, who sits in front of the hoiler, having inmodiately in fromt of him the stering apjaratus on his right, and on his left a serios of loyer's for starting the "ngine, or throwing the wheels ont of gral. The entire might of tho machine is about six toms, and by a simple (ontrivane the power of the sngine is trobled, so as to enable it to aseend the sterest grades, and the rubber tires on the wherls. in aldition to giving them the most perefert andhesion, aret as re ritahle load rollers, lolling the tow path smoth, and kesping it in good reprair. The pressure of stram repuiled to enable the rngine to draw three barges, is one hmucled pounds to the syuare inch, and that pressure ean he kept up with a ansmmetion of one hundered and fifty pounds of coal per Holl1: 
At a preliminary trial on Trestay, the steamer towed three barges (two loaded and one enjuty), the first mile in thipteen minutes; the second in fifteen minutes. and the thint in serenteen mimntes: it was also proved that the steepest grade conld be ascended and desconded with the greatest ease; that the engine could tmm in its own length, and was under perfect control.

The trial before the canal commissioners, however, took place yrsterday, when the following commissoners were plesent: Messis. Wright, Fay, and Barelay; also, a deputation from the hoard of trade of this city. Simerintendent North. and other's.

At the appointed time. the engine aserended the incline from the Troy road to the tow path, and hitched on to one of three bull-head barges, which were standing loaded with lumber, south of the arsenal, and having movers it into position. adopted the same comse with the serond? and thind, mutil they were aranged as a tow and properly secured. A rope from the engine having bersl made fast to the foremost hoat, the engine started, and drew them with the greatest rase, at the rate of three and a half miles an home, io the leck just above the rity, where she tumed romen, and having malle finst to anothere loaded hatrge, going north, took that in tow with the simeresult.

The greatest satisfaction was expresised by all plesent at the sucerestul working of the stemere and it must not be fergotten that it doess its work without any change whaterese being made wither in the ranal or boats.

The follewing is an estimate of the companative expemse of

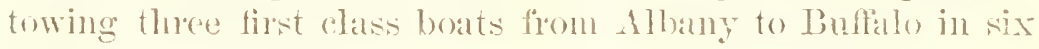
days,

\section{By the Williamson Road steamer.}

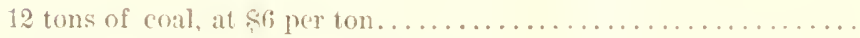

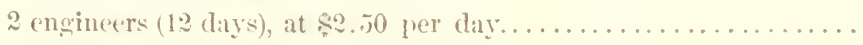

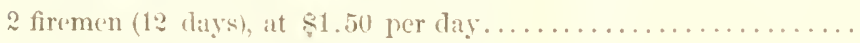

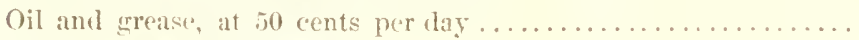

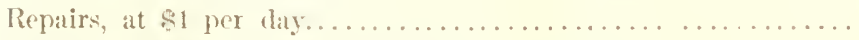

Interest on $\$, 000$, at $\tau$ per cent for $\tau$ months.............

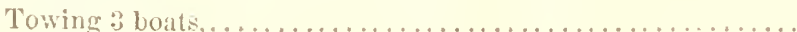


Towing 1 boat,

To make the comparison with horse towage and expenses of

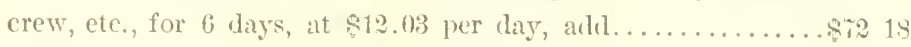

Interest on cargo for 6 days, at 96 eents per day, .......... \% 76 rir 94

C'ost of transportation by 1 boat by road steamer in 6 days.... 13904 C'ost of transportation by 1 boat by animal power in 10 days... $\quad 20290$

Faving per boat by use of road steamer, 4 days and ......... \$ $1: 39$

\section{By the Betyrum. system.}

The company estimate a tug to burn 2 tons of coal per diy, and to make the trip in six days, at a ruming expense of 40 per

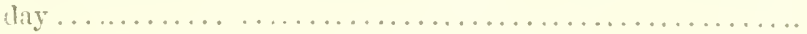

Add interest at 7 per eent., and depreciation 10 per cent on cable

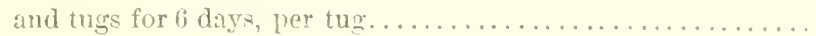

\section{B!/ Propetlor.}

From the oflicial report of the trips of the Dawson, it is evidest that no economy was shown over animal towage, when taking into eonsiderition the diminished cargo eapacity of the steamboat.

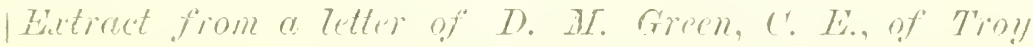
(the engineer apmointed b!y the Cand Alored ctommissioners to examine all stombonts compuling for the

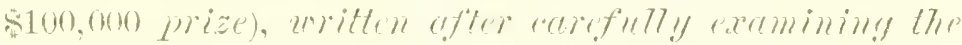
operation of a Williamson Road steamer, on the Erite Cand. and estimuting the cost of ruming, ste.]

"I lawe no doubt you will be alse to tow three Inaded hoats, at a speed of there mites per hour, at one-helf the present expense of horse towage."

[Fron tire "Albaix Aluges," Acgest $2,18 \%$. ]

\section{CANAT, TONFAGE.}

Mr. O. F. Potter, of West Troy, has written the following letter to Mr. I). 1). Williamson:

"Denr SiR: I was present and witnessed the several experi- 
ments with your road steamer upon the canal between Albany and Troy. After carefully observing the several trials, I am fully convinced that the principle of towing from the bank is the most practical and effectual mode as yet proposed for quickening and cheapening transportation nuon our canals. It leaves the narigator at liberty to patronize this mode or refuse it. just as he pleases.

"I camnot see any objections to it being applied to toring purposes at once, which can be done by gradual application at different points on the canal. Its strange apperarane and noise of steam is nothing more than the circumstance of applying steam. which of necessity has had to be overcome on different occasions, for the last forty years." 

$\div$

$$
\begin{aligned}
& 3 x=3 \\
& r=6 \\
& 4 \%=60 \\
& 3+2 \quad=80 \\
& 33+0=195
\end{aligned}
$$
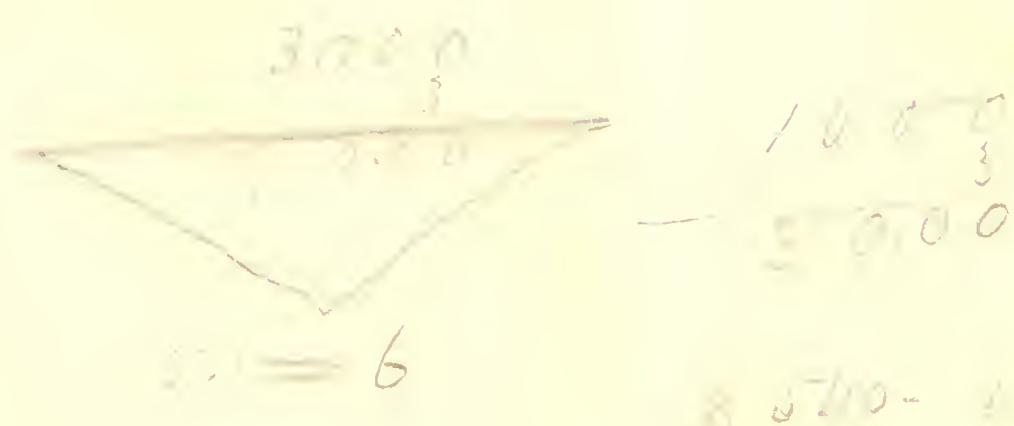

